\title{
Electron-microscope Studies of Nodule Development in Some Glover Species
}

\author{
BY BARBARA MOSSE \\ Soil Microbiology Department, Rothamsted Experimental Station, Harpenden, \\ Hertfordshire
}

(Received 27 November 1963)

SUMMARY

In this account of the fine structure of a nitrogen-fixing clover nodule the interactions between host and bacteria have been particularly considered. It is suggested that the bacterial infection is located between the paired membranes of the endoplasmic reticulum, i.e. within the intrareticular space. It is shown that the plant membrane around the infection thread is continuous with the plasmalemma, but that it is fragmentary around the thread tip. Bacteria emerging from the infection thread remain surrounded by a plant membrane, and their subsequent fate (division or rapid swelling) is controlled by the condition of the host cytoplasm. Structural changes occurring in the cytoplasm, nuclear region and wall of emerged bacteria during their transition to the bacteroid form are described, and the development of peripheral carbohydrate platelets in the host cell is illustrated. Supporting observations on two types of ineffective nodules are discussed.

\section{INTRODUCTION}

At the level of the light microscope the general histology of leguminous nodules is by now well known, but at the level of the electron microscope only some aspects, notably the structure of the bacteroids, have been studied. A more general account of bacteroid development in barrel medic and subterranean clover (Dart \& Mercer, $1963 b, c)$ has been published since this paper was written. The fine structure of rhizobia in culture was investigated by Baylor, Appleman, Sears \& Clark (1954) in the early days of electron-microscopy, and has been studied with present-day techniques by Vincent, Humphrey \& North (1962). Bergersen \& Briggs (1958) and Jordan (1962) examined the structure of bacteroids in crushed nodule fractions. In soya bean nodules Bergersen \& Briggs (1958) have described membranes of plant origin enclosing groups of bacteria, and Bergersen \& Wilson (1959) suggested that these membranes are the primary site of nitrogen fixation. Similar membranes enclosing single bacteroids have recently been described in other leguminous nodules (Dart \& Mercer, 1963a; Mosse, 1963; Jordan, Grinyer \& Coulter, 1963); their origin is described in this paper, and the exact location of the infection within the host cell is discussed. Other observations concern the structure of the infection thread, the way in which the bacteria emerge from it, the changes in bacterial structure that accompany the transition from the rod-shaped to the bacteroid form, and the influence of the host on this transition.

The histology of nodules of the type examined in the present work is well illus- 
trated by Thornton $(1930 a, b)$, McCoy $(1932)$ and Schaede $(1940,1941)$ on whose descriptions the following summary is based. Fåhraeus (1957) and Nutman (1959) have described the early stages of root hair infection. In the root hair the bacteria remain enclosed in a hypha-like structure-the infection thread--within which they multiply. The infection thread which depends for its growth on the close proximity of the nucleus, extends into the inner cortex where its approach stimulates certain tetraploid cells to divide (Wipf \& Cooper, 1940), thus initiating the meristem of the nodule. The mature infection thread is surrounded by a sheath, which reacts histochemically like the host cell wall and contains cellulose, probably laid down by the host cytoplasm. At its tip the infection thread appears to be without a sheath, and is thought to consist of a zoogloeal strand containing bacteria suspended in a mucilaginous matrix secreted by them. The formation of the thread wall is regarded by most observers as a typical defence reaction against an invading organism. In a somewhat different interpretation Nutman $(1956,1963)$ suggested that the infection thread may never penetrate into the plant cell cytoplasm, but that its matrix may represent an extension of the primary cell wall modified by bacterial action.

Bacteria emerge from the thread in one of three ways: as coccoid rods from the young unsheathed infection thread, by the bursting of vesicle-like swellings which arise on older sheathed parts of the thread, or, in some species, by a delayed release into cells already filled with bacteroids. Observations with the light microscope suggest that the bacteria released into the cytoplasm grow into elongated rodshaped organisms with a banded structure. In this form they may continue to divide, but eventually enlarge and develop into the much swollen, sometimes branched forms described as bacteroids. The criteria distinguishing rods from bacteroids are ill-defined. The distinction is based mainly on morphological characters (see reviews by Jordan, 1962; Raggio \& Raggio, 1962), and the present observations suggest that in clover nodules the transition point would be difficult to define. The generally accepted concept is that rods can divide and have a single nuclear region, whereas bacteroids cannot divide, have several discrete nuclear regions or do not react with Feulgen reagents, and are associated with nitrogen fixation. Eventually the bacteroids collapse. Unchanged bacteria remaining in infection thread fragments become parasitic, and their multiplication in the middle lamella probably causes the collapse of the nodule tissue.

\section{METHODS}

Nodules from seedlings of Trifolium parviflorum L., grown under sterile conditions in a nitrogen-deficient medium containing mineral salts and inoculated with an effective nitrogen-fixing strain (su 297) of Rhizobium trifolii, were used in the main investigation. A less detailed examination was also made of the pink bacteroidcontaining zone in nitrogen-fixing nodules of T. repens L., Vicia faba L. and Vicia hirsutum L., and of non-fixing nodules in T. parviflorum (inoculated R. trifolii Cl.F.) and $T$. repens (inoculated $R$. trifolii H.K.C.) The seedlings were grown in a glasshouse during autumn and winter, with supplementary artificial light. The nodules of $T$. parviflorum have a single apical meristem and are elongated when mature. Four main regions (Fig. 1) representing different developmental stages in the symbiotic process are macroscopically distinguishable. 


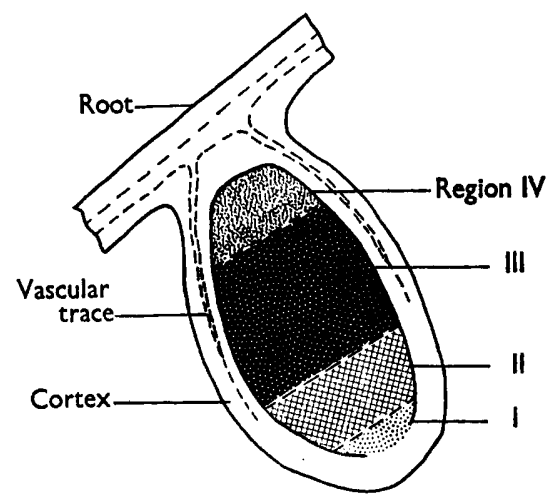

Fig. 1. Zones representing different stages of development in a nitrogen-fixing nodule of $T$. parviflorum. I, Meristematic zone containing dividing cells with large nuclei and very young infection threads; II, zone of expanding cells containing many rod-shaped bacteria and proliferating infection threads; III, pink-coloured zone with vacuolated cells containing bacteroids; IV, greenish-coloured zone containing collapsing cells and disintegrating bacteroids.

Electron microscopy. In the main investigation nodules of two different ages were examined: 5-day-old nodules from 2-week-old plants, and 4-week-old nodules from 8- and 10-week-old plants. Tissue slices $(0.5 \mathrm{~mm}$. thick) of the four zones were prepared for electron microscopy. Most of the material was fixed in $2 \%(w / v)$ potassium permanganate at room temperature for $2 \mathrm{hr}$. Some was also fixed in Palade's fixative (Mercer \& Birbeck, 1961) for $1 \frac{1}{2} \mathrm{hr}$, followed by $1 \%(\mathrm{w} / \mathrm{v})$ uranyl acetate for $\frac{1}{2} \mathrm{hr}$. The material was then dehydrated slowly and embedded in araldite, with xylene as a solvent. Sections were cut with a Huxley ultramicrotome and examined with a Siemens electron microscope.

Light microscopy. Two techniques were used to assist in the interpretation of structures seen by electron microscopy. Comparable nodules were sectioned on a freezing microtome and the sections stained and mounted in lactophenol containing a little cotton blue. Additional observations were made on small slices of the araldite-embedded tissue cut off with a razor blade and mounted on a slide in unpolymerized araldite. Infection threads, bacteria and cell walls were stained brown by the permanganate and were clearly visible.

\section{RESULTS}

\section{The infection thread}

Plate 1, fig. 1, shows a typical infected cell from the meristematic tip (region I) of a nodule. The cell contains an infection thread (cut transversely) and many bacteria distributed throughout the cytoplasm, as well as the usual cell organelles (proplastids, mitochondria, Golgi bodies, endoplasmic recticulum) and a central nucleus. Plate 1, fig. 2 (region I), shows an infection thread (L.S.) passing through a cell and shedding bacteria near the nucleus. In the material examined such direct passage through cell walls was uncommon; more often threads appeared to originate from a distended part of the wall and to terminate within the cell. Plate 2, fig. 3 
(region I), shows a thread that apparently originated in the wall and extended into two different cells.

The characteristic structure of a fully developed infection thread in region $I$ is shown in Pl. 3, fig. 4. The electron-dense central area consists of bacteria surrounded by a substance (here called the thread matrix), which looks unevenly dense after permanganate fixation but is homogeneous and opaque when fixed with osmium tetroxide. This matrix, which resembles the bacteria in its histochemical reactions (Schaede, 1940), is surrounded (Pl. 3, fig. 4) by the middle lamella, from which it differs, by the cell wall and by a cytoplasmic membrane continuous with the plasmalemma of the host cell. The cytoplasmic membrane and the area that will develop into thread wall are clearly shown in the small thread protrusion (Pl. 3, fig. 4, bottom right), but the middle lamella is not visible. Plate 3, fig. 5, shows the mature wall of two infection threads (T.S.) from an older part of a nodule (region II), where the host cells were already highly vacuolated. Cell cytoplasm, confined between the plasmalemma and tonoplast membranes, is limited to a thin peripheral layer lining the cell walls and surrounding the infection threads. A pocket of cytoplasm containing a mitochondrion is attached to the right-hand thread. One bacterium is embedded in an extension of wall substance, another lies in the pocket of cytoplasm and the others lie within the thread matrix. These pictures show that mature parts of infection threads are surrounded by a wall continuous with that of the host cell. They confirm the view, based on histochemical tests, that this wall is of host origin.

There is no wall around the growing tip of the infection thread. The close association between the host nucleus and the extending thread has been mentioned, and often the thread tip was seen lying in a deep indentation of the nuclear surface. This is shown in Pl. 4, fig. 6 (region I), where a thread tip is surrounded by the nucleus on three sides. Some bacteria are present quite close to the tip. In this region the thread matrix appears to lie freely within the host cytoplasm (see also Pl. 4, fig. 7) and only some rudimentary fragments of an enclosing membrane are visible. The only structural evidence of the special relationship between thread growth and the proximity of the nucleus are the very fine fibrils radiating from the thread surface towards the nucleus (see also Pl. 15, fig. 27). Near the growing point of a thread the normal cytoplasmic pattern of the cell is often much disturbed, with endoplasmic reticulum in the form of short pieces with relatively wide lumen and an accumulation of mitochondria and Golgi bodies (Pl. 2, fig. 3).

\section{Release of bacteria from thread and vesicles}

Bacteria can be released from infection threads at different times (in region I, II or III) and in different ways, but they always emerge without adhering thread matrix, and immediately become surrounded by a cytoplasmic membrane of host origin. Plate 4, fig. 7 , shows emergence in region I from very young threads not yet enclosed by a wall. It seems that the movement of bacteria into the cytoplasm cannot, as was thought, be attributed merely to internal pressures caused by bacterial multiplication and slime formation in the thread. The cap of thread matrix being pushed aside by the emerging bacterium (B) in the main picture apparently does not penetrate into the cytoplasm but remains enclosed within the plant 
membrane, and the thread wall develops behind it. Such caps were seen attached to the surface of young threads, and also of larger structures (Pl. 5, fig. 9).

As the thread ages, direct emergence is prevented by the thickening wall, but continues from two auxiliary structures: localized knob-like protruberances or swellings of the thread (Pl. 5, fig. 8) and delicate blister-like vesicles that arise laterally (Pl. 6, fig. 10). The structure illustrated in Pl. 5, fig. 9 (region II) is essentially a distended thread. Its wall is thinner than that of a normal thread, and disappears almost completely where bacteria are touching it. The thread matrix is less dense and granular, and the electron-transparent area around the bacteria is larger, than in very young threads (Pl. 4, figs. 6, 7). A bacterium on the point of emergence can be seen on the left. A true vesicle, shown in Pl. 6, fig. 11 (region II), has no enclosing wall and is interpreted as an extrusion of thread contents-matrix (now even less dense), and suspended bacteria (now surrounded by an even larger electrontransparent area)-into the host cytoplasm, from which they are separated by only a plant membrane. The bacterium shown in longitudinal section in Pl. 6, fig. 11, is near to emergence. During this process, further illustrated in $\mathrm{Pl} .7$, fig. 12 (region II), the thread matrix is characteristically left behind.

The interpretation of the electron-transparent zone, which increases around the bacteria with prolonged retention in the thread, is problematical. It may represent a polysaccharide secretion of the bacteria, an area from which some substance has been leached during processing, or less probably a lysogenous cavity. In lightmicroscope studies of Neptunia oleracea, Schaede (1940) noted unstained areas around the bacteria in infection threads, but was uncertain whether they were real or artifacts of fixation. Bacteroid development does not begin till the bacteria have emerged also from the transparent zone. An example of delayed or arrested emergence, into a host cell situated in the pink zone (region III) of a nodule and already containing mature bacteroids is shown in Pl. 7, fig. 13. Several groups of bacteria are contained in electron-transparent areas enclosed by a cytoplasmic membrane. Where the bacteria touch the membrane they are swollen and, as in earlier emergence the membrane is distended locally (Pl. 5, fig. 9). Eventually, protruding bacteria become completely surrounded by the plant membrane and pass into the cytoplasm by a process of apparent ingestion (also shown in $\mathrm{Pl}$. 13, fig. 23).

The swelling of bacteria that approach the vesicle or thread boundary so close that there is no intervening matrix, and the subsequent distortion of the plant membrane, appear to be fundamental steps in the process of emergence. Schaede's (1941) view that the thread matrix protects the bacteria from the lytic effects of the host cytoplasm is supported by these observations.

\section{The development of the enclosing membrane system}

Figure 2 shows the interrelation between the membrane systems of the nucleus, the cytoplasm and its organelles, and the position the infection thread and bacteria are thought to occupy within this system. The bacterial infection is shown as developing between the paired membranes of the endoplasmic reticulum which will be referred to as the intra-reticular space. The now widely accepted concept of a continuous intra-reticular space, stretching from the cell surface to the nucleus, is based on the observed continuity between the nuclear membrane and the endo- 
plasmic reticulum and its continuity through the plasmodema (Robertson, 1959; Whaley, Mollenhauer \& Leech, 1960; Setterfield, 1961; Buvat, 1963). Irregularly shaped areas, interpreted as expanded intra-reticular space, were common in the cytoplasm of meristematic nodule cells (Pl. 1, fig. 2; Pl. 2, fig. 3). Characteristically such areas were enclosed by a single unit membrane which at the sharply pointed corners appeared to merge into the normal endoplasmic reticulum ( $\mathrm{Pl}$. 1, fig. 2, middle right), and contained small round vesicles $50-130 \mathrm{~m} \mu$ in diameter. These

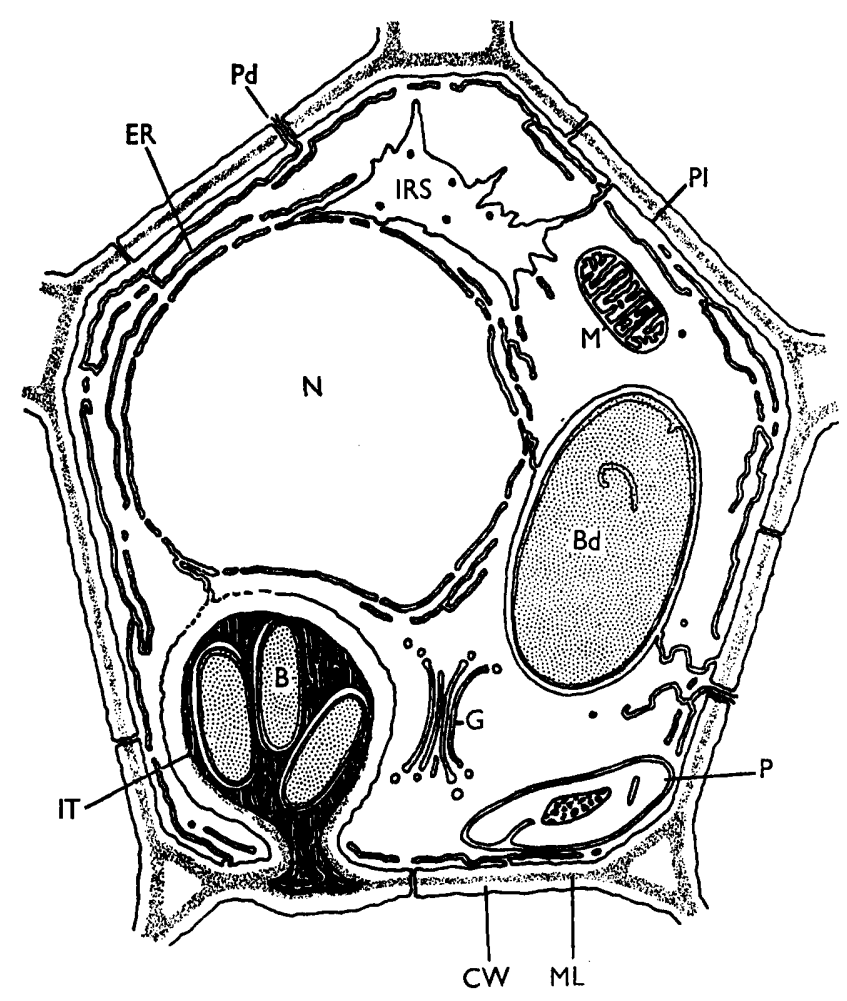

Fig. 2. Diagrammatic representation of the position of the bacterial infection in a nodule cell. B, Bacteria; Bd, bacteroid; CW, cell wall; ER, endoplasmic reticulum; G, Golgi body; IRS, intra-reticular space; IT, infection thread; $M$, mitochondrion: ML, middle lamella; N, nucleus; $P$, proplastid; Pd, plasmodesma; Pl, plasalemma.

areas resemble the pre-vacuolar bodies described by Whaley, Mollenhauer \& Kephart (1962) in maize cells, but neither the very early stages in which prevacuolar bodies are more electron dense than the surrounding cytoplasm, nor later stages (seen by kind permission of Dr B. E. Juniper) in which their contents more resembled those of true vacuoles, were seen in clover. Whaley et al. (1962) consider that 'the pre-vacuolar body change to the vacuole is a specific organelle transformation'; other views about the origin of plant vacuoles are discussed by Buvat (1963) and Marinos (1963). In clover, these areas contained a substance similar to the cytoplasm and quite unlike vacuolar sap, and occurred in young meristematic cells, while true vacuoles developed much later. A separate investigation would be 
needed to determine whether they are forerunners of true vacuoles; for the purpose of this paper, they will be considered as expanded intra-reticular space.

In Pl. 1, fig. 2 (top left), an enlarged intra-reticular space is seen apparently continuous with a very large gap in the nuclear membrane. A large opening in the nuclear membrane also occurs in the central nucleus in Pl. 1, fig. 2 and similar pores were common in nuclei in region I. In older parts of the nodule the nuclear pores were of more normal size, 50-100 $\mathrm{m} \mu$ according to Setterfield (1961). Very large pores, associated as in clover nodules with abnormal configurations of the nuclear membrane and adjacent endoplasmic reticulum, have also been illustrated by Whaley et al. (1960) and by Leech, Mollenhauer \& Whaley (1963) in root tip cells of maize. If such large gaps in the nuclear membrane are a characteristic of the polyploid nucleus in a meristematic tissue they may have some connexion with the role of the tetraploid nucleus in nodule development.

The cytoplasmic membranes surrounding the infection thread are unit membranes in the sense of Robertson (1959), averaging $7 \mathrm{~m} \mu$ in width. Continuity between the thread membrane and the plasmalemma is illustrated in Pl. 1, fig. 2, Pl. 2, fig. 3; and Pl. 3, figs. 4, 5; but near a thread tip (Pl. 4, figs. 6, 7) or in other parts of a young thread close to the nucleus (Pl. 1, fig. 2) the membranes are fragmentary, possibly because of active synthesis, and their origin and connexion with the membrane system of the host cell are difficult to follow. Whether the thread membrane is regarded as a spontaneous new formation, possibly originating from Golgi bodies which are often nearby (Pl. 4, fig. 6), or as a continuous extension of the plasmalemma, which around the thread tip loses the appearance of cohesion, depends on one's views about the origin of cytoplasmic membranes. Plate 8, fig. 14, provides evidence that the plant membrane around recently emerged bacteria is continuous with the normal endoplasmic reticulum. Whether such continuity persists when the enclosed bacteria begin to swell is difficult to determine. Although there is often a strong suggestion of continuity, undoubted connexions are rare in the later stages, and the envelopes may separate completely from the endoplasmic reticulum. Open connexions between the enclosing membrane and the endoplasmic reticulum were common in one type of ineffective nodule (Trifolium repens inoculated with Rhizobium trifolii H.K.C.; Pl. 8, fig. 15).

The origin of membranes around bacteria emerging later from vesicles or distended threads can more easily be traced. The existing membrane around these subsidiary structures simply extends and closes up behind the emerging bacterium. During subsequent development this membrane, which originated in the host cytoplasm, behaves more like a bacterial than a plant membrane and is further considered below.

\section{Changes in rhizobial structure associated with their transition from the rod-shaped to the bacteroid form}

Rhizobia undergo two important developments in the nodule; they multiply and they increase in volume more than tenfold. The swelling is associated with changes in the nuclear region, the cytoplasm and the bacterial wall. These changes are illustrated diagrammatically in Fig. 3.

Rhizobia in the rhizosphere. Plate 8, fig. 16, shows some rhizobia near a root hair. They have a large irregularly shaped nuclear region in the centre, surrounded by a 
narrow region of denser cytoplasm. Some bacteria contain a small electrontransparent vacuole near one end. The protoplast is surrounded by two unit membranes averaging 7-9 $\mathrm{m} \mu$ in diameter, separated by a less dense inter-membrane area. By analogy with the structure of other Gram-negative bacteria (Martin, 1963; Salton, 1960) and in agreement with the interpretation of Dart \& Mercer $(1963 a, b, c)$ and Vincent et al. (1962) the inner is regarded as the cytoplasmic membrane and the outer as the outside layer of the rigid bacterial wall. The intermembrane area is wide (of the order of $50 \mathrm{~m} \mu$ ) and very irregular. This may be attributable in part to shrinkage or natural invagination of the cytoplasmic membrane but, as pointed out by Vincent et al. (1962), this space is by no means devoid

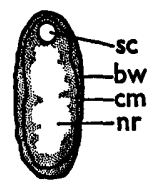

1

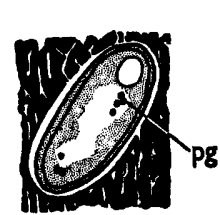

2

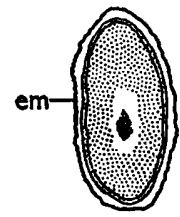

3

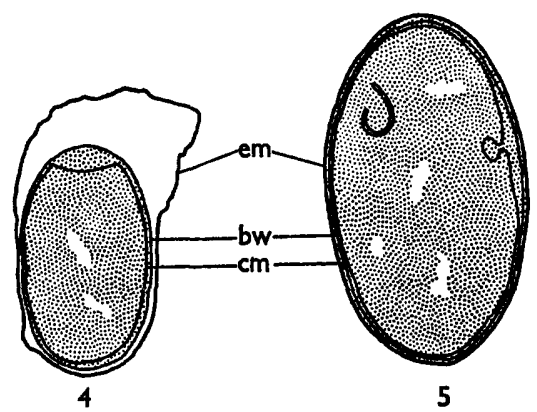

Fig. 3. Changes in bacterial structure during nodule development. 1, Bacteria in rhizosphere; 2 , bacteria in infection thread; 3 , bacteria recently emerged into the host cytoplasm and still dividing; 4 , final stage in bacteroid formation; 5 , bacteroids. bw, Bacterial wall; cm, cytoplasmic membrane of bacterium; em, enclosing membrane of plant origin; $\mathrm{nr}$, nuclear region; sc, storage carbohydrate; pg, polyhedral granule.

of electron-dense material. Since it persists and becomes much more regular and wall-like during subsequent developments, it probably has some structural reality and must presumably be regarded as an interior non-rigid layer of the bacterial wall. The considerable enlargement of the inter-membrane area at the bacterial poles, which was observed by Vincent et al. (1962) in cultured rhizobia, was not seen in those from the rhizosphere.

Rhizobia in threads and vesicles. The rhizobia undergo only minor changes while they are enclosed in the infection thread. Those found in immature parts of the thread and likely to emerge early (Pl. 4, figs. 6, 7) have a clearly defined cytoplasmic membrane nearly parallel to that of the bacterial wall. Rhizobia left in the thread divide, mainly by constriction (Pl. 3, fig. 4), and those in vesicles by a process more like budding (Pl. 6, fig. 11). In such bacteria the nuclear area condenses while the 
cytoplasm enlarges correspondingly, and the round or oval vacuoles within it increase in size (Pl. 3, fig. 4; Pl. 6, fig. 11). Their ontogeny (to be described elsewhere) and their similarity to deposits of the storage carbohydrate poly- $\beta$-hydroxybutyric acid (PHBA) in Hydrogenomonas sp. (Schlegel, Gottschalk \& von Bartha, 1961) make it probable that they are of a similar nature, but they might be normal cytoplasmic vacuoles. PHBA has been isolated from leguminous nodules (Forsyth, Hayward \& Roberts, 1958; Schlegel, 1962) and from rhizobia in culture (Vincent et al. 1962), although the latter authors observed only few vacuoles in cultured rhizobia containing up to $50 \%$ (w/v) PHBA.

Electron-dense approximately polyhedral particles of about $50 \mathrm{~m} \mu$ diameter appear in the bacteria retained in threads and vesicles, mainly in regions II and III (Pl. 6, fig. 11; Pl. 3, fig. 4; Pl. 4, fig. 7; Pl. 7, figs. 12, 13). They bear much resemblance to precursor-phage particles in Escherichia coli (Kellenberger, 1961), but are not necessarily confined to the nuclear region. In nodules the particles rapidly disappear when the bacteria emerge into the host cell, except occasionally where an emerged bacterium filled with such particles has developed no further. Investigations in progress may show whether these particles are connected with phage infection, and if so whether this is a peculiarity of the strain su 297 or has any general significance for nodule development.

Rhizobia in the cytoplasm. Plate 1, figs. 1, 2, and Pl. 8, fig. 14, show bacteria in region I recently emerged into the host cytoplasm. After emergence the bacterial cytoplasm immediately begins to swell, accompanied by loss of the carbohydrate vacuoles and further shrinkage of the nuclear region. This is now clearly separated into a dense central portion, possibly indicating a more condensed form of DNA (Kellenberger, 1962), and a less dense perinuclear area. These trends are further illustrated in Pl. 9, fig. 17, which shows some bacteria about to divide. The host cell still contains a prominent nucleus and dense cytoplasm with Golgi bodies and structure characteristic of a meristematic cell.

The next stage (Pl. 9, fig. 18) occurs when the cytoplasm in the expanding host cell (region II) becomes dispersed and much less electron dense, and the bacteria no longer divide. Contrary to the widely accepted view that rod-shaped bacteria divide until they reach the bacteroid stage in region III, there was no convincing evidence that division occurred in vacuolating cells. The implications of this observation relating bacterial multiplication to the state of the host cytoplasm are further discussed below.

Plate 9, fig. 18, also illustrates changes in the spatial relationship of the bacterial wall and its associated membranes. The enclosing host membrane becomes more prominent and begins to fold. The two bacterial membranes approach one another closely so that the original inter-membrane space narrows, and the inner cytoplasmic membrane develops characteristic invaginations. The various stages of invagination illustrated in Pl. 9, fig. 18, are consistent with the explanation that the bacteria in region II are imbibing materials from the host cytoplasm by a process of pinocytosis (Suganuma, 1961). Plate 10, fig. 19 (osmium tetroxide fixation), shows the further expansion of the plant membrane enclosing the bacteria. This membrane now differs from the other plant membranes around vesicles of the host cytoplasm by the absence of the small electron-dense particles (about $5 \mathrm{~m} \mu$ diameter) thought to be ribosomes, that give to the vesicular membranes the characteristic appearance 
of rough reticulum. The two mitochondria identify the ground tissue as host cytoplasm.

The final stage in bacteroid formation (Pl. 11, fig. 20) is associated with the formation of a central vacuole in the host cell; the transition to the haemoglobin-containing tissue (region III) occurs very quickly. The host membrane around the bacteria is now fully expanded leaving a large space between it and the bacterial wall which will be occupied by the developing bacteroid. This space is occupied by a substance resembling vacuolar fluid. As the central vacuole develops in the host cell, the cytoplasm and enclosed bacteria are pushed towards the periphery, and as the bacteria expand the cell organelles are compressed and begin to disintegrate. At this stage the bacteria no longer have a single recognizable nuclear area; small, irregularly shaped, less dense areas in the cytoplasm probably represent the fragmented nucleus.

Swollen bacteria similar to those in the host cell were sometimes seen in intercellular spaces (Pl. 13, fig. 23), which also contained unidentifiable tissue fragments. Characteristically such bacteria had only two membranes and lacked the one produced by the host cytoplasm.

Plate 12, fig. 21, shows fully developed bacteroids from region III. These are surrounded by three unit membranes (Pl. 12, fig. 22) of which the plant membrane (about $10 \mathrm{~m} \mu$ across) is now the most clearly defined. The ground tissue of the bacteroids looks exactly like that of the surrounding cytoplasm, and apart from the electron-transparent fragmented nuclear material, occasional invagination of the inner cytoplasmic membrane and some internal vesicles surrounded by compound membranes, they have no organized structure. No Golgi bodies, only small fragments of endoplasmic reticulum and very few mitochondria remain in the host cytoplasm.

The structural changes undergone by the bacteria in the cytoplasm, viz. swelling fragmentation of the nuclear region, formation of a uniformly granular cytoplasm and the folding and expansion of the outer enclosing membrane, have some similarity to those associated with the early stages of phage infection in Escherichia coli (Kellenberger, 1961).

\section{Degenerative changes}

Plate 14, fig. 25, shows the final disintegration of bacteroids and host cell in region IV. The cell wall breaks down, often by splitting at the middle lamella as shown; in later stages no continuous wall structure is left. The bacteroid membranes disintegrate and the original bacteroid shapes are only just discernible in the clumped tissue mass (Pl. 14, fig. 25). Young, actively dividing bacteria similar in size and structure to those of the rhizosphere are found in the split wall cavities and also among the collapsing bacteroids and in the cell vacuole. Only the faintly visible electron-dense particles within them suggest the influence of the host environment.

\section{Cell carbohydrates}

Raggio \& Raggio (1962) reviewed information about the storage carbohydrates of nodules and their possible link with nodule metabolism. In effective nodules of Trifolium parviflorum and some other species, uninfected cells contain compound starch grains while adjacent infected cells do not. In several clover species a more 
soluble polysaccharide, tentatively identified as a dextran by Bergersen (1957), occurs as a temporary deposit in a narrow transition zone between regions II and III. This carbohydrate occurs in the shape of rectangular platelets characteristically arranged opposite the intercellular spaces and around the cell periphery.

Plate 1, fig. 1, shows proplastids in region I with starch grain precursors (oval, densely granular bodies) in an uninfected cell, and with what appear to be eluted remains of such precursors in adjacent cells containing bacteria (see also Pl. 1, fig. 2; Pl. 2, fig. 3). In older infected cells in region II the empty proplastids tend to occur near the cell periphery; often they appear to be compressed by the expanding bacteria. In these peripheral plastids the rectangular carbohydrate platelets develop, appearing first as densely granular bodies (Pl. 17, fig. 20) and later becoming electron-transparent (Pl. 13, fig. 23). Well-developed mitochondria frequently occur near them. In their development the platelets closely resemble normal starch grains, but they differ in their characteristic rectangular shape.

In some nodules from an 8-week-old seedling of Trifolium repens a system of parallel lamellae, each a unit membrane, occurred in the otherwise empty plastids (Pl. 13, fig. 24). These structures somewhat resemble the grana of chloroplasts. The ribbon-like structure below the plastid is a swollen cell wall split at the middle lamella and filled with some secretory or breakdown products from a nearby group of intercellular bacteria like those in Pl. 13, fig. 23.

\section{Additional observations on other material}

It is as yet unknown to what extent symbiotic nitrogen fixation is linked to the structural organization of the bacteroid zone. More information about the nodules of other species will help to determine which developmental stages are important in establishing the symbiotic relationship. Some further observations on the structure of the bacteroid zone in other nitrogen-fixing combinations, and of general nodule structure in two non-fixing combinations, are given in this section.

Effective nodules. The structure of bacteroids in the pink zone (region III) of Vicia faba, V. hirsutum and Trifolium repens was essentially similar to that of $T$. parviflorum; each bacteroid was surrounded by a unit membrane of plant origin. A similar arrangement was found by Dart \& Mercer (1963a) in Medicago tribuloides, T. subterraneum and species of Acacia, Vicia, Vigna, and Viminaria. Jordan et al. (1963) pictured bacteroids of Medicago sativa enclosed in a double membrane not apparently present when the bacteria first emerged from the thread, but preservation of bacterial structure in these pictures was not good, and the theories advanced for the origin of the enclosing membrane are curious.

Ineffective nodules. Genetic and anatomical investigations (Nutman, 1959) have shown that ineffectiveness-the inability to fix nitrogen symbiotically-can be based on different factors and that normal nodule development can be interrupted at different stages. Two types of ineffective nodules were examined. Neither contained bacteroids, but the structural patterns of ineffectiveness differed.

In nodules of Trifolium parviflorum inoculated with Rhizobium trifolii Cl.F. infection thread contents and cell organelles looked normal (Pl. 15, fig. 27), except for a notable lack of cytoplasm even in quite young cells near the nodule meristem. Possibly because of this, the thread wall was frequently rudimentary or lacking, as in Pl. 15, fig. 27, although the size of the electron-transparent area around the bac- 
teria suggests that this was a mature infection thread. Emergence was much delayed, and when it occurred (often from vesicles) the thin cytoplasmic lining around the vesicle was broken, so that the bacteria emerged into the vacuole where they did not develop further. A few rod-shaped bacteria were seen in freshly cut sections; it is assumed that these emerged into small pockets of cytoplasm like those shown in Pl. 15, fig. 27, and developed normally, but none was encountered in the electron-microscope preparations. In older parts of the nodule the bacteria often multiplied in the distended cell wall which sometimes ruptured, as in Pl. 15, fig. 28; in the lower cell both nucleus and cytoplasm are disintegrating. These observations show that without the stimulation of cytoplasmic activity which the approaching infection thread normally induces in prospective host cells (Thornton, 1930b), few bacteria emerge from the thread, and there is no habitat in which they can multiply and swell. Evidently the central vacuole, even in an apparently normal cell, does not supply the necessary environment.

A much more drastic reaction occurred between Trifolium repens and Rhizobium trifolii (H.K.C.), both bacteria and host cells showing advanced collapse. Although the cell nucleus appeared normal and enlarged as in effective nodules, the cytoplasm even near the meristematic nodule tip was again scarce, and all the cell membranes (tonoplast, plasmalemma, endoplasmic reticulum) were fragmentary (Pl. 14, fig. 26). The matrix of young infection threads was much more electron transparent than in any of the other nodules examined, and in older parts of the nodule no trace of it remained. In some cells of the meristem there was enough cytoplasm for apparently normal release of bacteria, but degenerative changes appeared very quickly in both cytoplasm and bacteria (Pl. 16, fig. 29). Enclosing membranes were initiated but rarely completed, and after an initial swelling the bacteria soon looked lysed. Tonoplast, plasmalemma and even the cell wall disintegrated completely. In some cells in regions I and II a quite extensive system of membranes was found around and between collapsing bacteria, but never enclosing them completely (Pl. 16, fig. 30). In older parts of the nodule there was a vigorous development of bacteria in the quite abnormally distended cell walls, together with a complete collapse of all cellular contents including any bacteria accidentally released into the cell. The structural pattern of ineffectivity in this combination strongly suggested a pathogenic condition.

\section{DISCUSSION}

The present investigation has provided some information about the structure and development of the infection thread by means of which the bacteria enter new cells, and it has demonstrated that bacterial development in the host cell, and perhaps also emergence from the thread, are closely linked with the state of the host cytoplasm.

Although some bacterial multiplication occurs in infection threads and vesicles, the bulk probably occurs after emergence into the host cytoplasm. The accumulation of carbohydrate reserves in bacteria prior to emergence suggests, by analogy with Hydrogenomonas (Schlegel et al. 1961) and other bacterial growth studies, that such bacteria have reached a stationary growth phase. Schaede (1940) also noted that bacteria immediately after entry into the cytoplasm divided much faster than before. According to electron-microscope evidence emerged bacteria divided 
only in the 'active' cytoplasm of physiologically young cells, whereas they swelled quickly and stopped dividing in the more 'dilute' cytoplasm of expanding cells. This disagrees with the widely accepted view, based on isolation experiments, that rod-shaped bacteria continue dividing until they reach the bacteroid form. Since, however, emergence is evidently a continuous process, and some recently emerged bacteria with relatively unchanged structure were found even in the bacteroid zone (region III), samples used for isolation experiments almost certainly contained bacteria at different stages of development. It is also possible that rod-shaped bacteria from region II can reproduce in culture and yet fail to do so in the nodule environment. Since the rate of vacuolation of the host cell must to some extent be influenced by the parent plant some observations relating growing conditions and nodule structure could also be interpreted on this basis. Schaede (1941) observed that nodules from rapidly growing plants contained relatively few large bacteroids in cells with large central vacuoles, whereas those from poorly growing plants had cells with small vacuoles containing many smaller bacteroids. Also Thornton's (1930 b) observation that darkened lucerne seedlings contained many infection threads with a tendency to swell into zoogloeal masses, could be related to the known effects of etiolation on cell expansion and vacuolation. If then the important phase of bacterial multiplication occurs in cells with an 'active' cytoplasm, the cytoplasmic activity induced in prospective host cells by the approaching infection thread, and the early emergence from immature threads are of particular importance in the formation of an effective nodule. The host cytoplasm may also play a role in emergence. The retention of bacteria within the infection thread in some ineffective nodules that conspicuously lacked 'active' cytoplasm suggests this, and the electron micrographs of emerging bacteria do not suggest that internal pressures within the thread, to which emergence has been attributed, are likely to be a primary cause. If the host cytoplasm performed some active function in emergence, this would explain how the infection thread passes from the root hair to the nodule site without shedding bacteria in the passage cells of the cortex which are highly vacuolated and have only a nar row peripheral layer of cytoplasm.

How rhizobia enter a root hair and how the infection thread passes across cell walls has long presented a problem, because in culture rhizobia have neither pectolytic nor cellulolytic ability. Sahlman \& Fåhraeus (1964) have obtained electron micrographs of entry into root hairs which, in their opinion, support an invagination hypothesis. From the present work no definite conclusion can be reached until more is known about the nature and origin of the thread matrix. If this is a bacterial secretion entry is probably brought about by bacterial action, direct or indirect, on the cell wall. The unexpected frequency of pockets of bacteria and thread matrix in distended splits of the middle lamella, also noted by Jordan et al. (1963) in alfalfa, suggests that, within the nodule, bacteria can exert some modifying influence on cell wall structure, especially when in a confined space. If, on the other hand, the thread matrix is some modified cell wall constituent, this would support invagination as a means of entry. Plasmodesma pores are clearly too small to offer any assistance as mechanical openings, although they may serve as channels of conduction for secretions from an infection thread, especially if the intra-reticular space is the site of the infection. 
The possible significance of membranes isolating the symbiont or parasite from its host has been discussed by Nutman (1968) and Garrett (1963). It is argued that intra-cellular symbionts and avirulent parasites may invaginate the cytoplasmic membrane without actually penetrating it, and so be less damaging to the host cell. In nodules the membrane at the tip of an infection thread is fragmentary so this concept may over-simplify the issue. That membranes by themselves are not always sufficient barriers against mutually destructive effects was demonstrated in one type of ineffective nodule where the uncontrolled formation of such membranes was a feature. There is, however, in the normal nodule enough affinity between the host cytoplasm and the bacterial surface to allow the enclosing plant membrane to function as if it were part of the bacterial wall, and to allow new membranes to become reorganized rapidly around the maturing infection thread and emerging bacteria without more disturbance than occurs in the formation of a new membrane at cell division.

Whether the membrane enclosing the bacteroid is indeed the primary site of nitrogen fixation remains to be proved. Since nitrogen fixation is generally regarded as confined to the bacteroid zone whilst enclosing membranes are formed immediately the bacteria emerge from the infection thread, these membranes can hardly be more than a necessary prerequisite for fixation, with other factors initiating the process.

This investigation was started at the suggestion of Dr P. S. Nutman and owes much to his continued interest and enthusiasm. I also acknowledge with grateful thanks the advice of Mr H. L. Nixon, and the work of Mr R. D. Woods and Mr A. A. Welch who did all the photography. Their technical knowledge and patient help were of the greatest assistance.

\section{REFERENCES}

Baylor, M. B., Appleman, M. D., Sears, O. H. \& Clark, G. L. (1945). Some morphological characteristics of nodule bacteria as shown by the electron microscope. J. Bact. 50, 249.

Buvat, R. (1963). Electron microscopy of plant protoplasm. Int. Rev. Cytol. 14, 41.

Bergersen, F. J. (1957). The occurrence of a previously unobserved polysaccharide in immature infected cells of root nodules of Trifolium ambiguum M. Bieb. and other members of the Trifolieae. Aust. J. biol. Sci. 10, 17.

Bergersen, F. J. \& Briggs, M. J. (1958). Studies on the bacterial component of soya bean root nodules: cytology and organization in the host tissue. J. gen. Microbiol. 19, 482.

Bergersen, F. J. \& Wirson, P. W. (1959). The location of newly-fixed nitrogen in soy nodules. Bact. Proc. 59, 25.

Dart, P. J. \& Mercer, F. V. (1963a). Membrane envelopes of legume bacteroids. J. Bact. 85, 951.

Dart, P. J. \& Mercer, F. V. (1963b). Development of the bacteroid in the root nodule of barrel medic (Medicago tribuloides Desr.) and subterraneum clover (Trifolium subterraneum L.). Arch. Mikrobiol. 46, 382.

Dart, P. J. \& Mercer, F. V. (1963c). The intracytoplasmic membrane system of the bacteroids of subterraneum clover nodules (Trifolium subterraneum L.). Arch. Mikrobiol. $47,1$.

FÅnRaEUS, G. (1957). The infection of clover root hairs by nodule bacteria studied by a simple glass slide technique. J. gen. Microbiol. 16, 874 .

Forsyth, W. G. C., Hayward, A. C. \& Roberts, J. B. (1958). Occurrence of poly- $\beta$ hydroxybutyric acid in aerobic Gram-negative bacteria. Nature, Lond. 182, 800.

Garrett, S. D. (1968). Soil fungi and soil fertility. Oxford: Pergamon Press. 
Jordan, D. C. (1962). The bacteroids of the genus Rhizobium. Bact. Rev. 26, 119.

Jordan, D. C., Grinyer, I. \& Coulter, W. H. (1963). Electron microscopy of infection threads and bacteria in young root nodules of Medicago sativa. J. Bact. 86, 125.

Kellenberger, E. (1961). Vegetative bacteriophage and the maturation of the virus particles. Adv. Virus Res. 8, 2.

Kellenberger, E. (1962). The study of natural and artificial DNA-plasms by thin sections. In The Interpretation of Ultrastructure. Ed. by R. J. C. Harris, p. 233. New York: Academic Press.

Leech, J. H., Mollenhauer, H. H. \& Whaley, W. G. (1963). Ultrastructural changes in the root apex. In Cell Differentiation. Ed. by G. E. Fogg. Cambridge University Press.

McCoy, E. (1932). Infection by Bact. radicicola in relation to the microchemistry of the host's cell walls. Proc. Roy. Soc. B, 110, 514.

Marinos, N. G. (1963). Vacuolation in plant cells. J. Ultrastructure Res. 9, 177.

MARTIN, H. H. (1963). Bacterial protoplasts-a review. J. theoret. Biol. 5, 1.

Mercer, E. H. \& Birbeck, M. S. C. (1961). Electron microscopy, p. 53. Oxford: Blackwell Scientific Publications.

Mosse, B. (1963). Rep. Rothamst. exp. Sta. 1962, p. 81.

Nutman, P. S. (1956), The influence of the legume in root-nodule symbiosis. A comparative study of host determinants and functions. Biol. Rev. 31, 109.

Nutman, P.S. (1959). Some observations on root-hair infection by nodule bacteria. J. exp. Bot. 10, 250.

Nutman, P. S. (1963). Factors influencing the balance of mutual advantage in legume symbiosis. In Symbiotic Associations. Symp. Soc. gen. Microbiol. 13, 51.

Raggio, M. \& Raggio, N. (1962). Root nodules. A. Rev. Pl. Physiol. 13, 109.

Robertson, J. D. (1959). The ultrastructure of cell membranes and their derivatives. Symp. Biochem. Soc. 16, 3.

Sahlman, K. \& Fảhraeus, G. (1964). An electron microscope study of root-hair infection by rhizobium. J. gen. Microbiol. 33, 425 .

Salton, M. R. J. (1960). Microbial Cell Walls. New York and London: John Wiley and Sons, Inc.

Schaede, R. (1940). Die Knöllchen der adventiven Wasserwurzeln von Neptunia oleracea und ihre Bakteriensymbiose. Planta, 31, 1.

Schaede, R. (1941). Untersuchungen an den Wurzelknöllchen von Vicia faba und Pisum sativum. Beitr. Biol. Pfl. 27, 165.

SchlegeI, H. G. (1962). Die Isolierung von Poly- $\beta$-hydroxybuttersäure aus Wurzelknöllchen von Leguminosen. Flora, 152, 236.

Schlegel, H. G., Gottschalk, G. \& von Bartha, R. (1961). Formation and utilization of poly- $\beta$-hydroxybutyric acid by Knallgas bacteria (Hydrogenomonas). Nature, Lond. 191, 463.

SETTERFIELD, G. (1961). Structure and composition of plant-cell organelles in relation to growth and development. Can.J. Bot. 39, 469.

Suganuma, A. (1961). The plasma-membrane of Staphylococcus aureus. J. biophys. biochem. Cytol. 10, 292.

Thonnton, H. G. (1930a). The early development of the root nodule of lucerne (Medicago sativa, L.). Ann. Bot. 44, 385.

Thornton, H. G. (1930b). The influence of the host plant in inducing parasitism in lucerne and clover nodules. Proc. Roy. Soc. B, 106, 110.

Vincent, J. M., Humphrey, B. \& North, R. J. (1962). Some features of the fine structure and chemical composition of Rhizobium trifolii. J. gen. Microbiol. 29, 551.

Whaley, W. G., Mollenhauer, H. H. \& Kephart, J. E. (1962). Developmental changes in cytoplasmic organelles. 5th int. Congr. Electron Microscopy, 2, W-12.

Whaley, W. G., Mollenhauer, H. H. \& Leech, J. H. (1960). The ultrastructure of the meristematic cell. Am.J. Bot. 47, 401.

WiPF, L. \& COOPER, D. C. (1940). Somatic doubling of chromosomes and nodular infection in certain Leguminosae. Am.J. Bot. 27, 821. 


\section{EXPLANATION OF SYMBOLS ON PLATES}

$\begin{array}{ll}\text { B } & \text { Bacterium } \\ \text { Bd } & \text { Bacteroid } \\ \text { CP } & \text { Carbohydrate platelet } \\ \text { CW } & \text { Cell wall of host cell } \\ \text { Cy } & \text { Cytoplasm of host cell } \\ \text { ER } & \text { Endoplasmic reticulum } \\ \text { G } & \text { Golgi body } \\ \text { IRS } & \text { Intra-reticular space } \\ \text { IS } & \text { Intercellular space } \\ \text { IT } & \text { Infection thread } \\ \text { M } & \text { Mitochondrion } \\ \text { ML } & \text { Middle lamella } \\ \text { N } & \text { Nucleus of host cell } \\ \text { Nmb } & \text { Nuclear membrane } \\ \text { P } & \text { Proplastid }\end{array}$

Pd Plasmodesma

Pl Plasmalemma

RR Rough reticulum

TM Thread matrix

Tmb Thread membrane

TW Thread wall

V Vacuole of host cell

Ve Vesicle

bw Bacterial wall

nr nuclear region of bacterium

cm Cytoplasmic membrane of bacterium

em Enclosing membrane of plant origin

sc Storage carbohydrate (PHBA?) of bacterium

\section{EXPLANATION OF PLATES}

Unless otherwise stated all micrographs are from tissue of nitrogen-fixing nodules of Trifolium parviflorum (inoculated with Rhizobium trifolii strain su 297, fixed in $2 \%(w / v)$ potassium permanganate.

\section{Plate 1}

Fig. 1. Meristematic cell (region I) containing an infection thread (cut transversely) and many bacteria distributed through the cytoplasm. The uninfected cell (above) contains proplastids with normal starch grain precursors; in the infected cell the precursors are shrunk or absent.

Fig. 2. Meristematic cell (region $I$ ) with an infection thread (cut longitudinally) passing across two cell walls and shedding bacteria in the vicinity of the nucleus. An intra-reticular space (top left), is apparently connected with a large pore in the nuclear membrane. Other large pores occur in the central nucleus. The membrane of the intra-reticular space (middle right) is continuous with the endoplasmic reticulum.

\section{Prate 2}

Fig. 3. An infection thread spreading from the cell wall into two adjacent cells. Around the thread tips and the small thread protrusion (middle right) the plant membrane enclosing the thread is fragmentary. In the lower cell the normal cytoplasmic pattern is much disturbed and there are two large intra-reticular spaces. At $\mathbf{P d}$ the endoplasmic reticulum appears to pass through a plasmodesma pore. Bacteria marked $B$ are about to emerge from the infection thread.

\section{Plate 3}

Fig. 4. An infection thread lying in a distended cell wall. The thread matrix (TM) is distinct from the substance of the middle lamella (ML). Bacteria about to divide are indicated by arrows.

Fig. 5. Mature infection threads in highly vacuolated cells (region II).

\section{Plate 4}

Fig. 6. Tip of an infection thread lying in an invagination of the host nucleus. The enclosing membrane of host origin is fragmentary or absent.

Fig. 7. Infection thread tip, situated near a nucleus not shown on the micrograph. The bacterium (B) is emerging, leaving behind an electron-transparent area that is not immediately filled up with thread matrix. (See also inset.)

\section{Prate 5}

Fig. 8. Localized swellings of an infection thread containing bacteria, region II. (Freezingmicrotome section.)

Fig. 9. Distended part of an infection thread in region II. The bacterium indicated by the arrow is near to emergence. Caps of thread matrix attached to the outside of the infection thread remain within the enclosing plant membrane. 

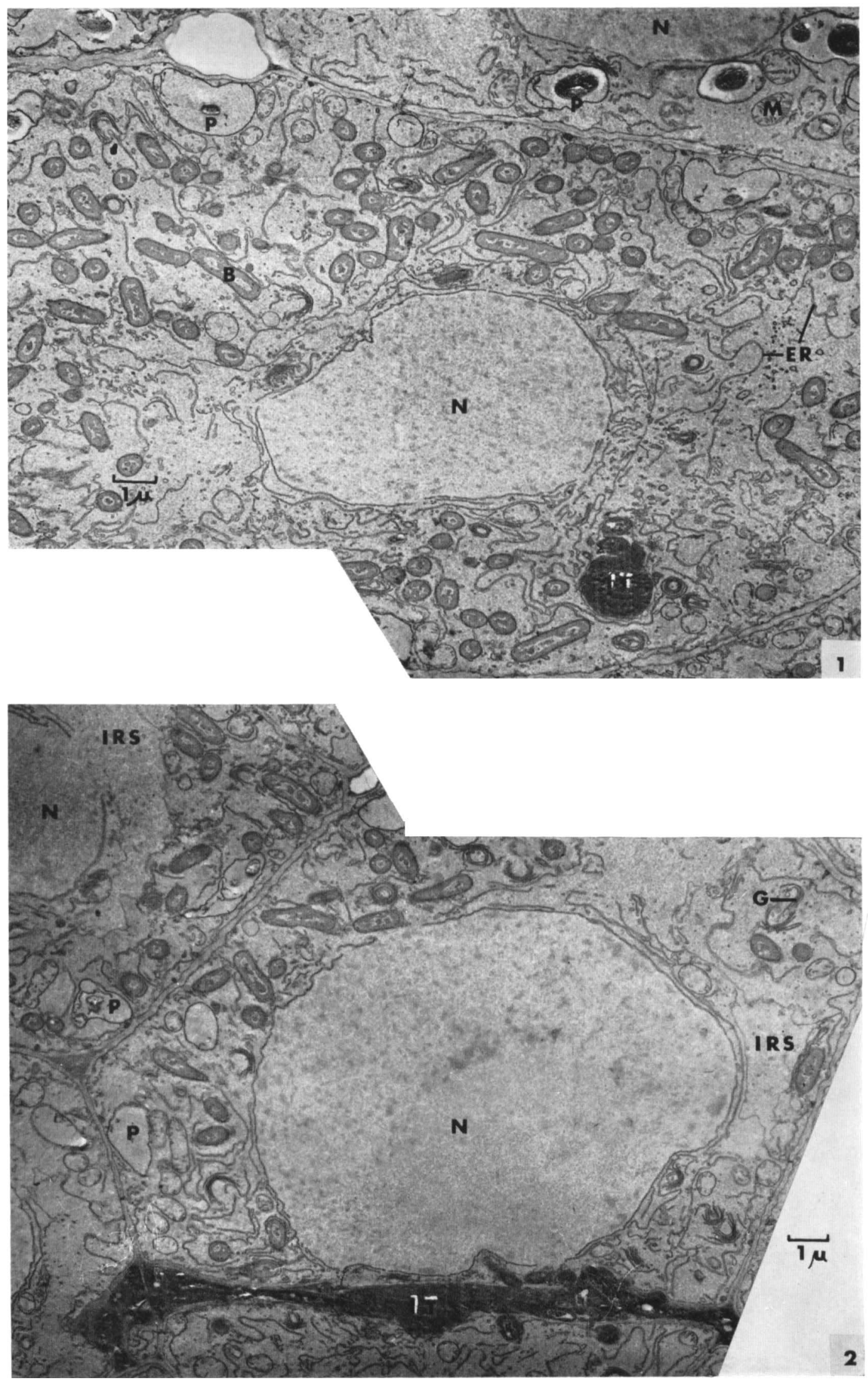


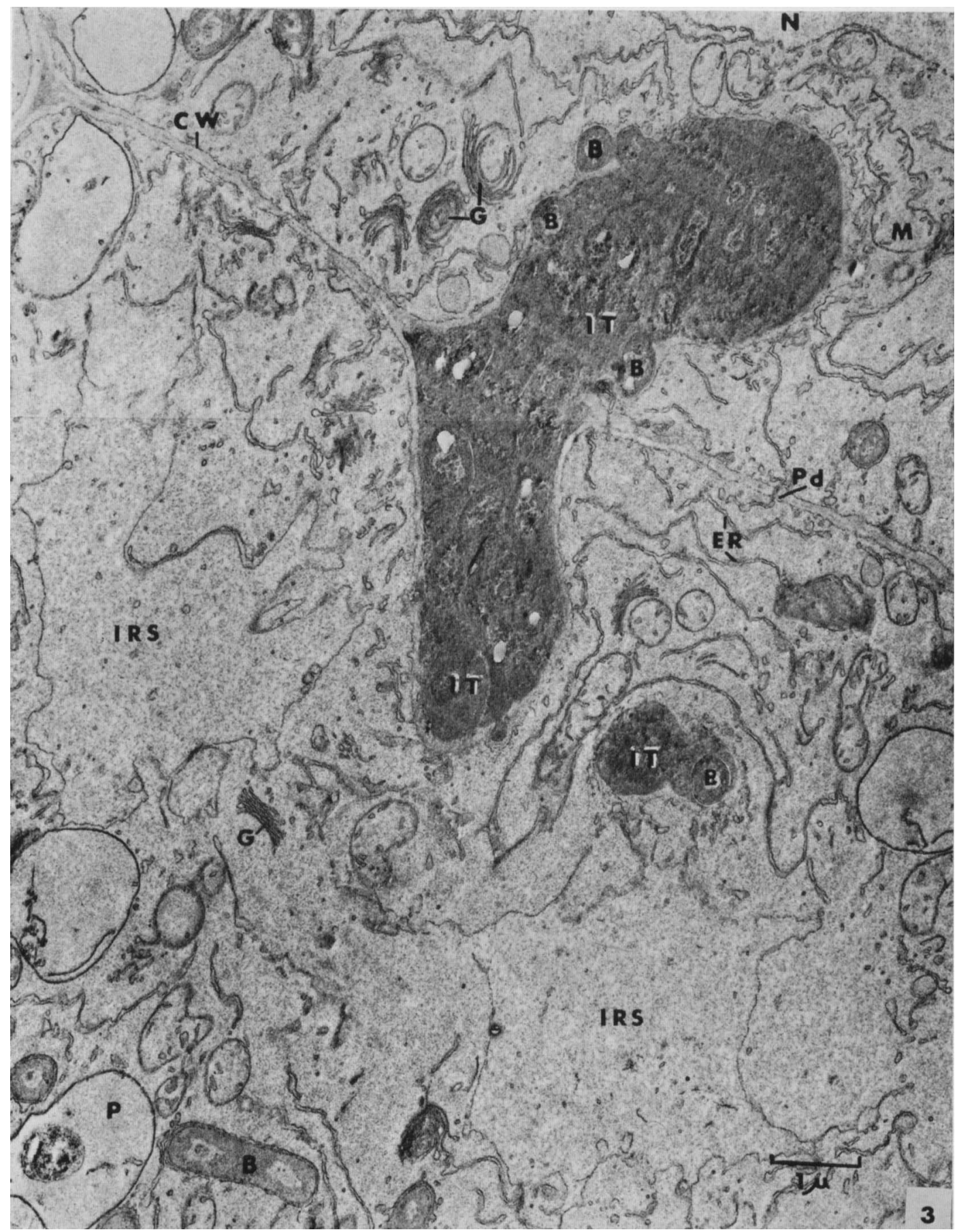

B. MOSSE 

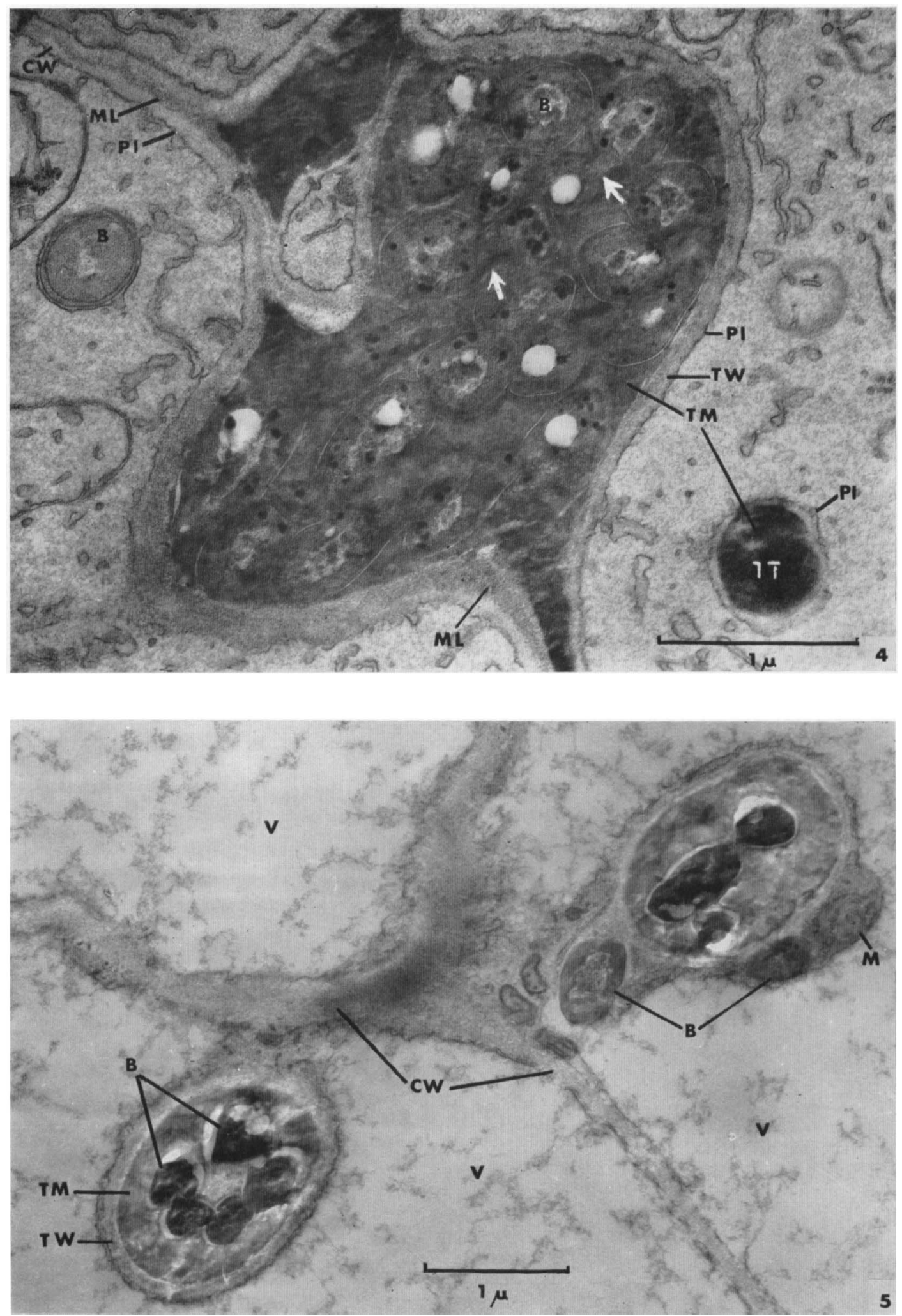

B. MOSSE 
Journal of General Microbiology, Vol. 36, No. 1

Plate 4
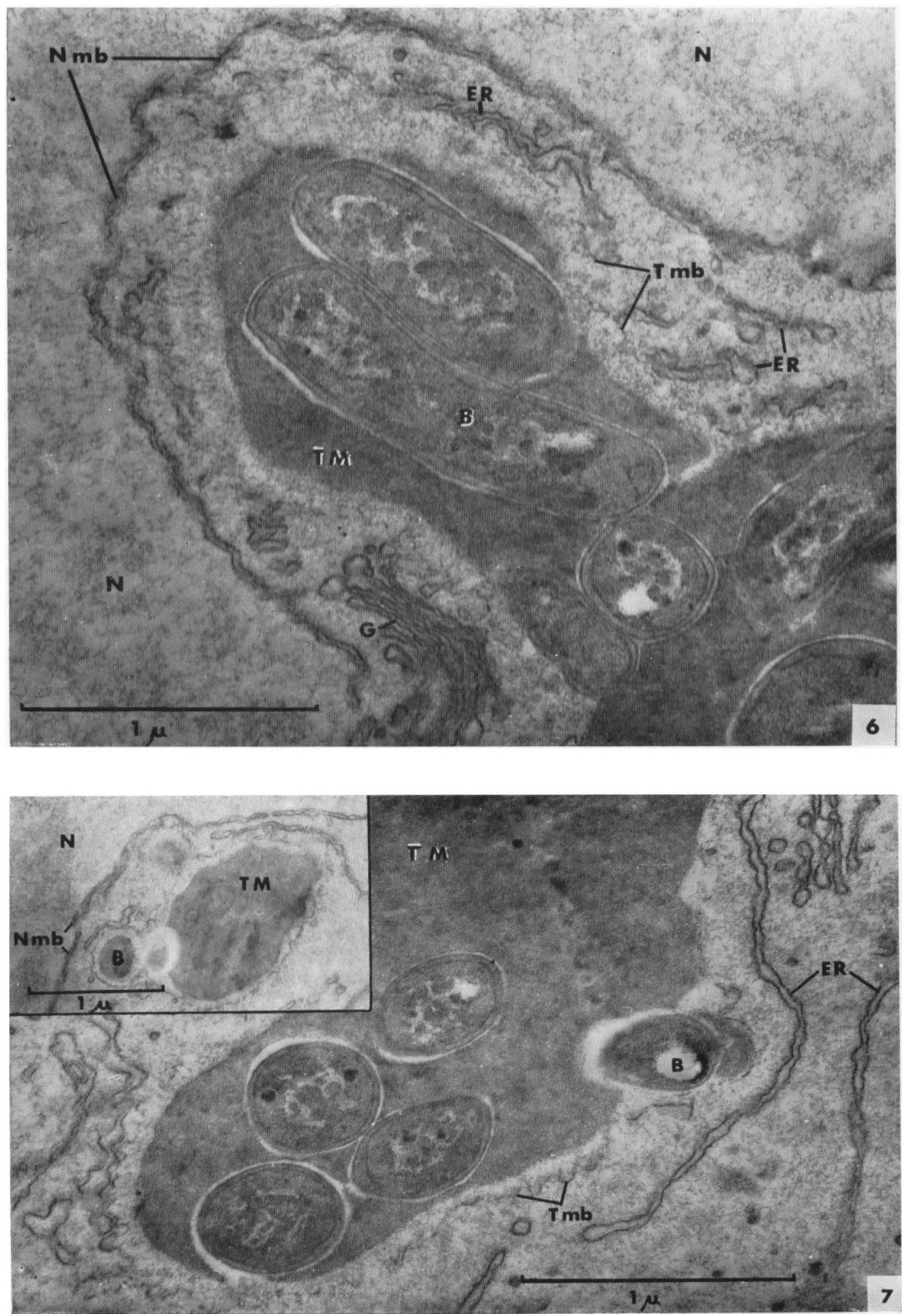

B. MOSSE 
Journal of General Microbiology, Vol. 36, No. 1

Plate 5
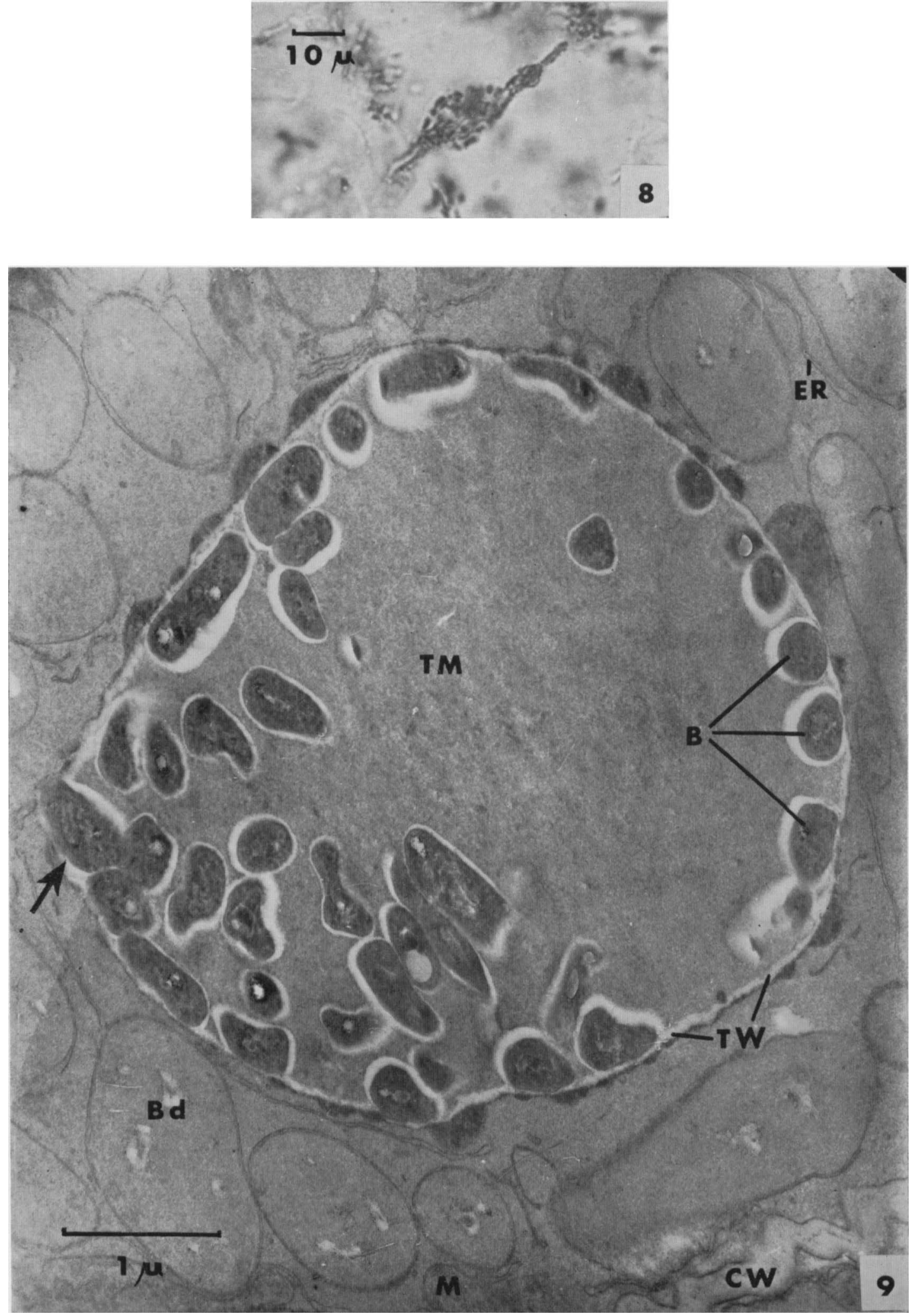

B. MOSSE 
Journal of General Microbiology, Vol. 36, No. 1

Plate 6
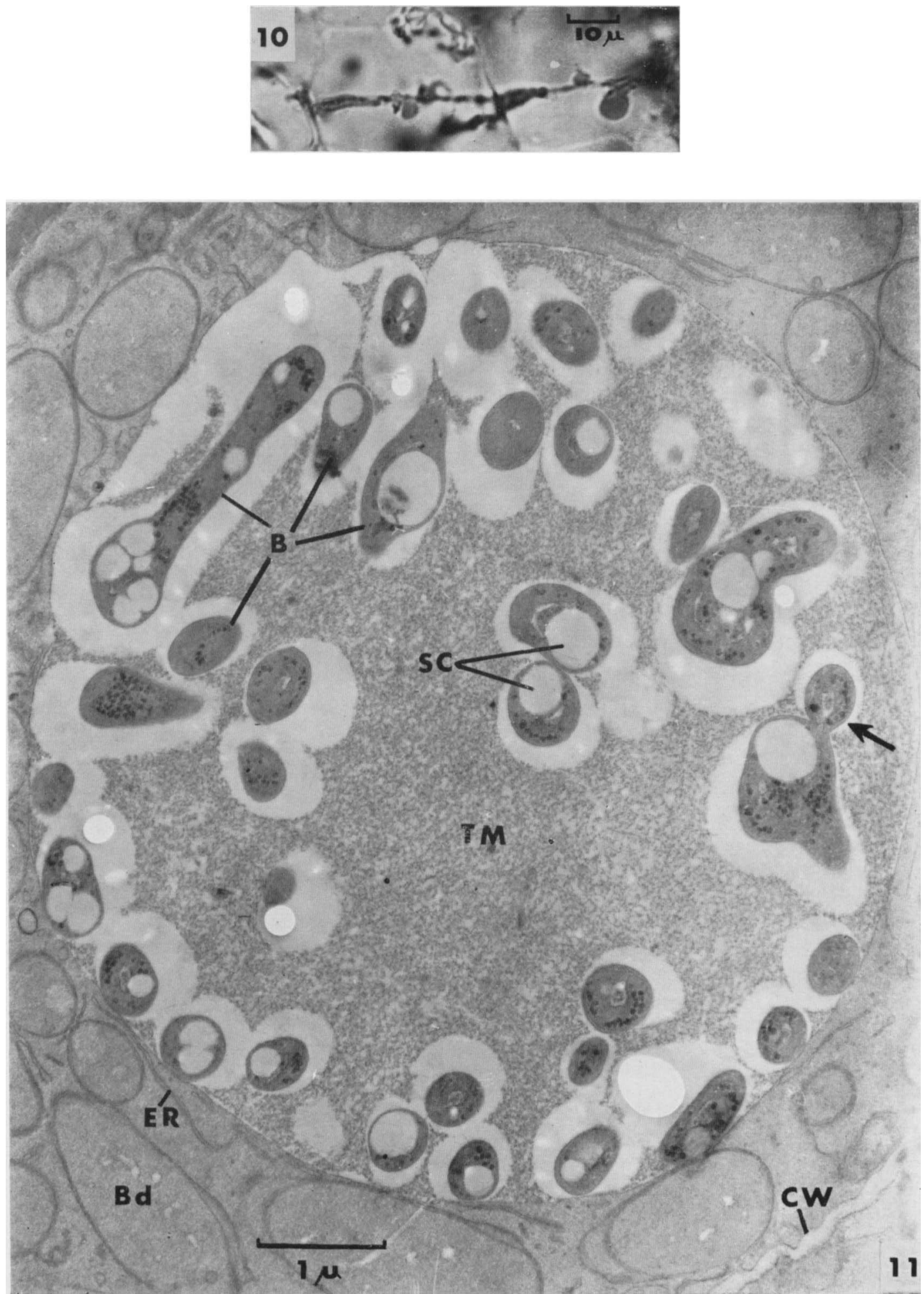

B. MOSSE 
Journal of General Microbiology, Vol. 36, No. 1

Plate 7
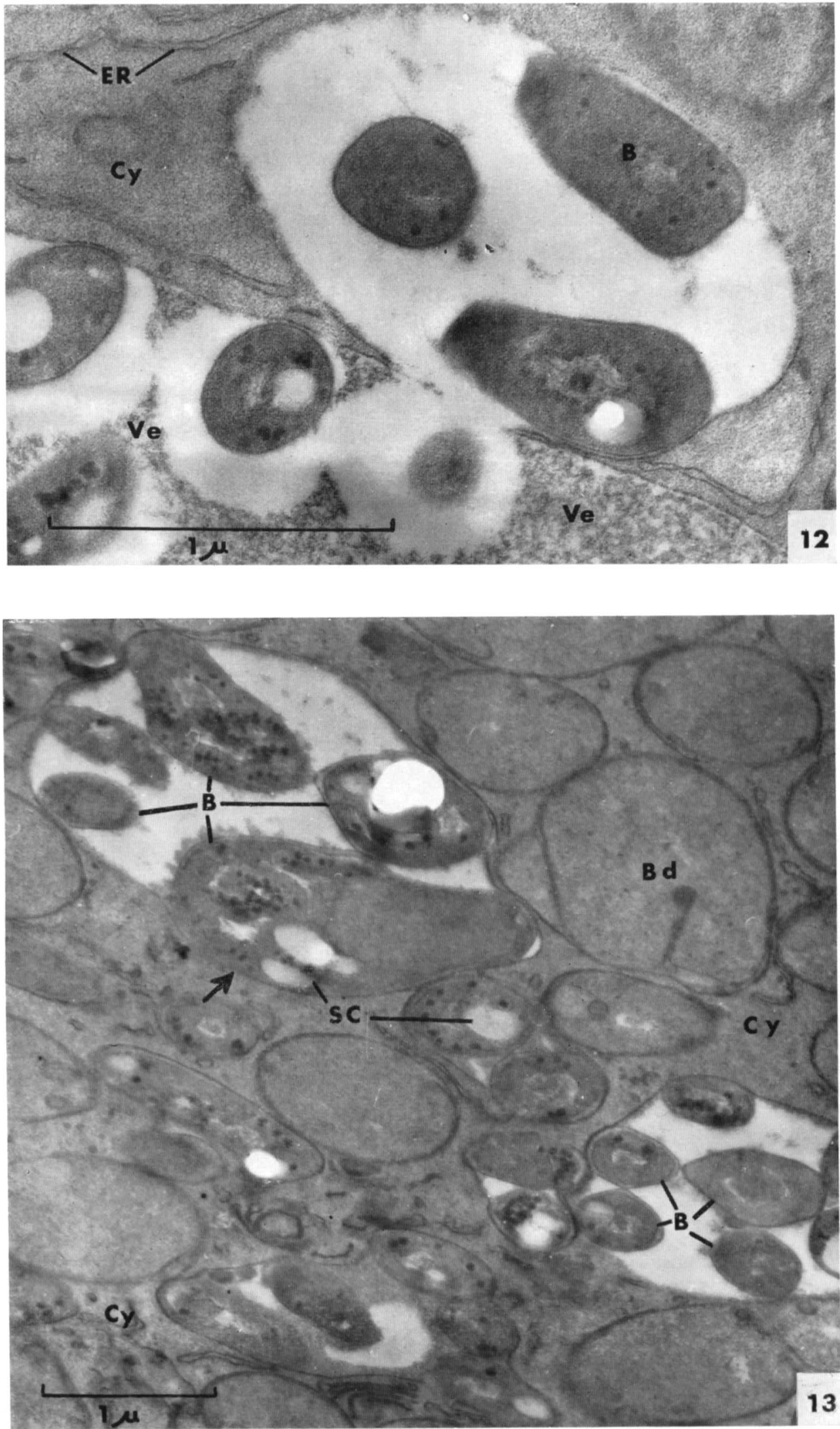

B. MOSSE 
Journal of General Microbiology, Vol. 36, No. 1

Plate 8
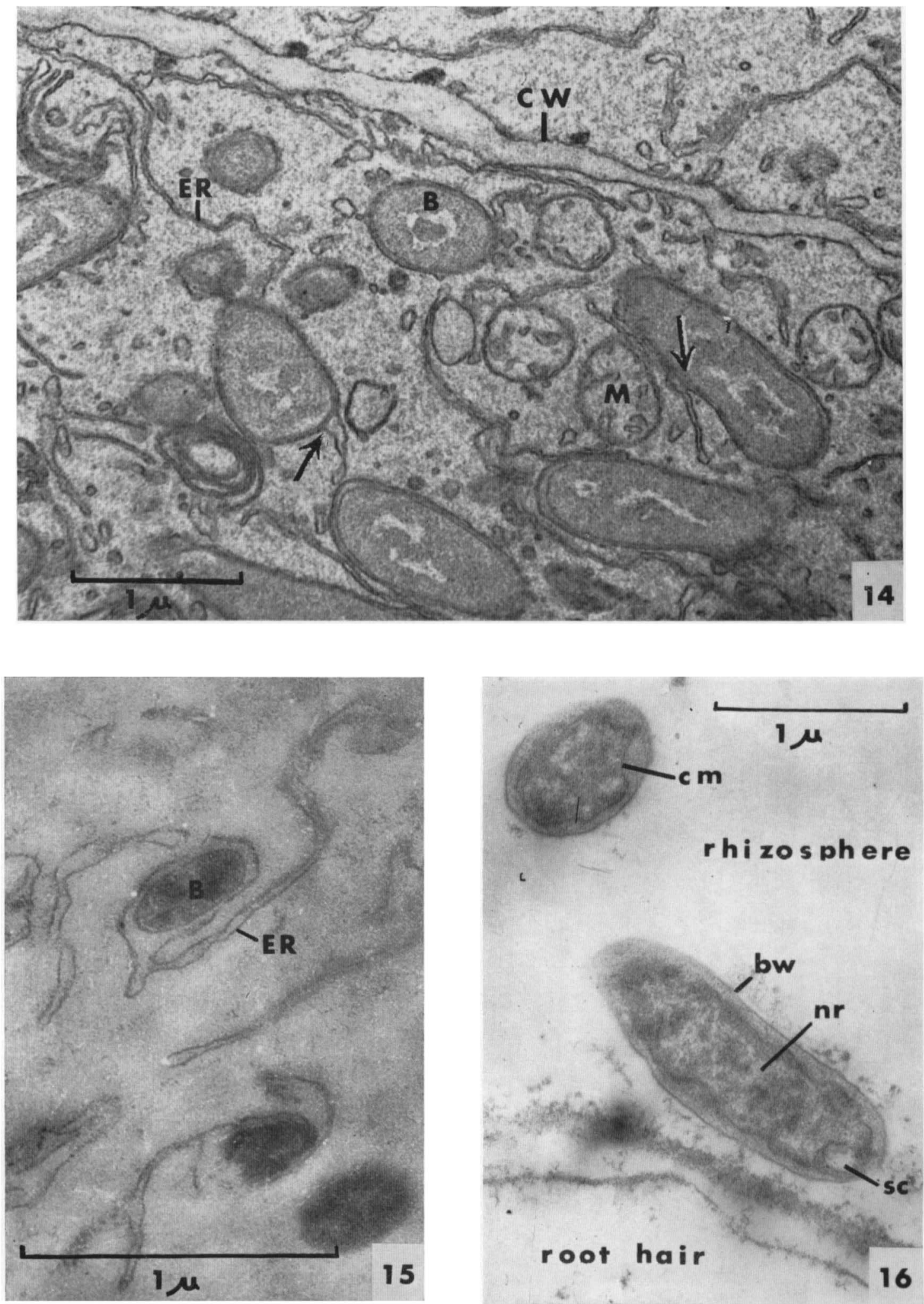

B. MOSSE 
Journal of General Microbiology, Vol. 36, No. 1

Plate 9
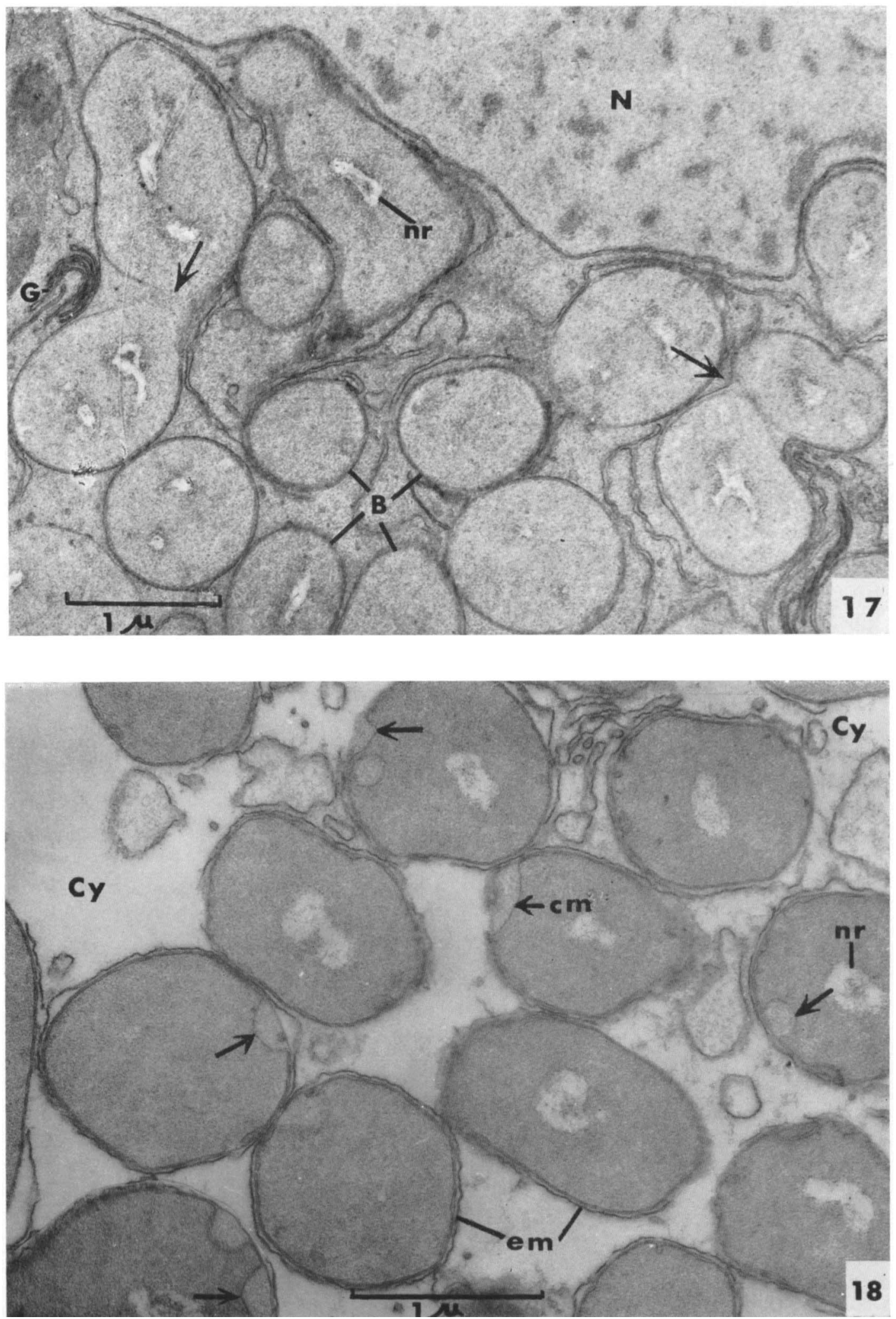

B. MOSSE 
Journal of General Microbiology, Vol. 36, No. 1

Plate 10

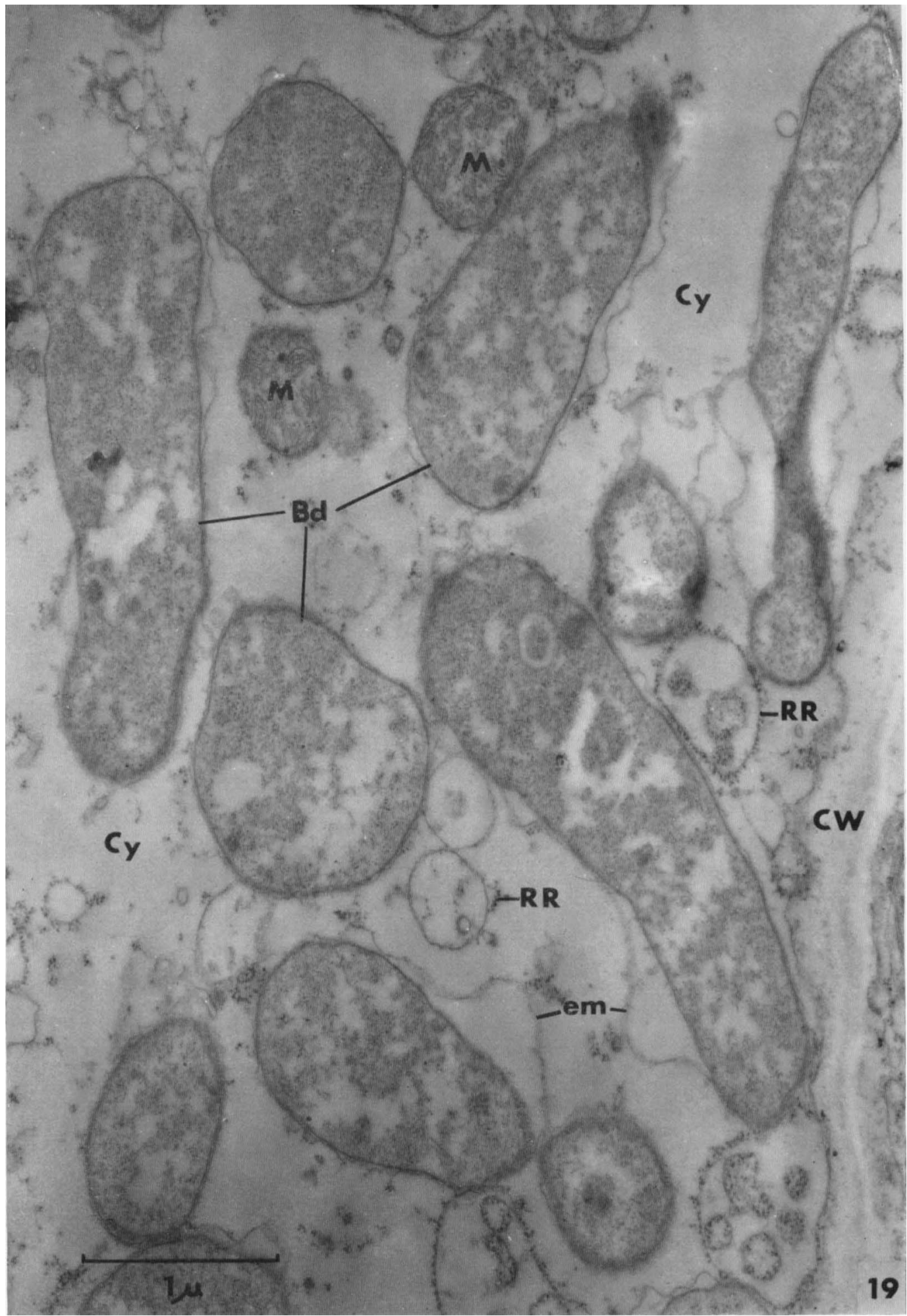

B. MOSSE 
Journal of General Microbiology, Vol. 36, No. 1

Plate 11

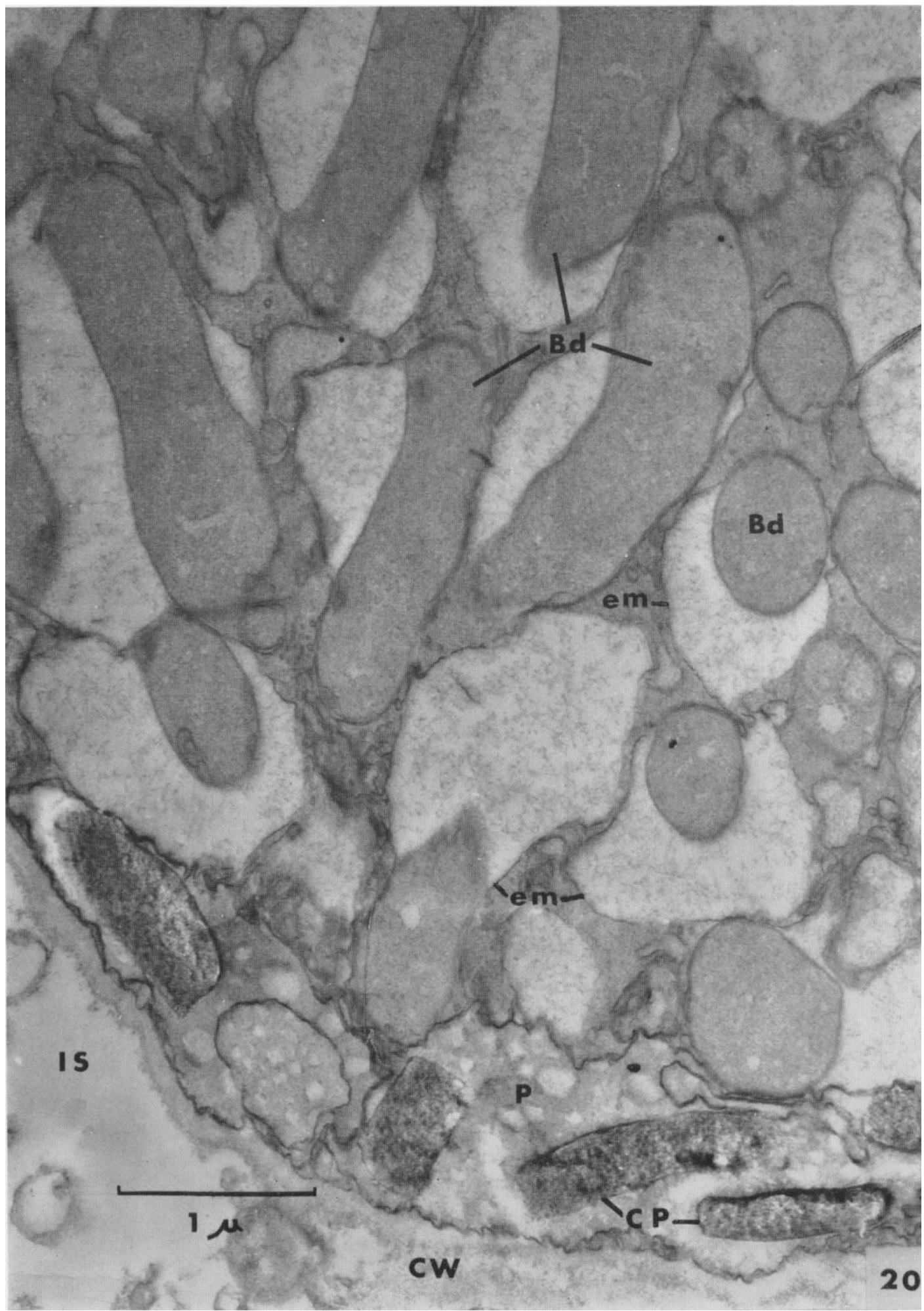

B. MOSSE 
Journal of General Microbiology, Vol. 36, No. 1

Plate 12
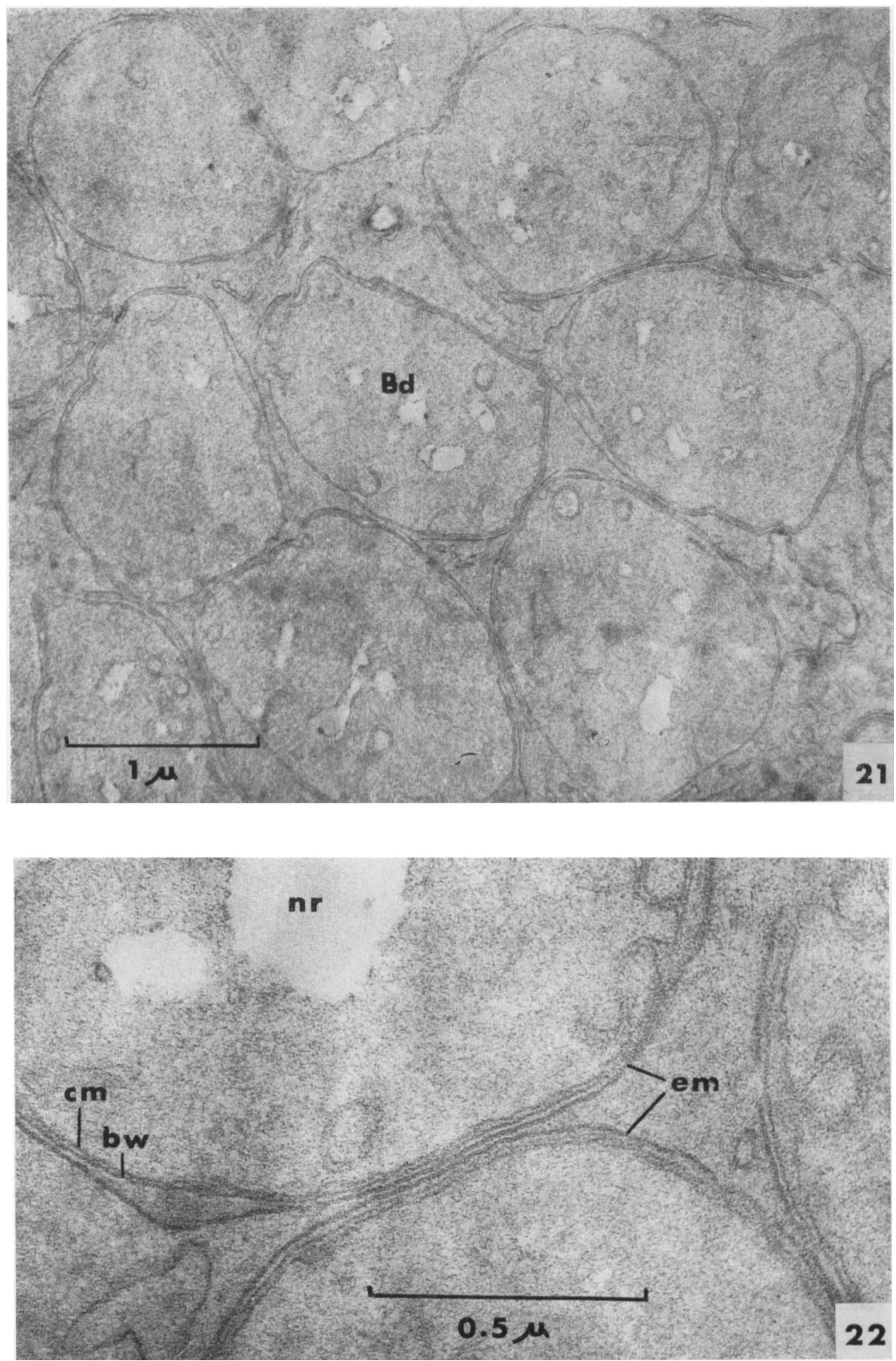

B. MOSSE 

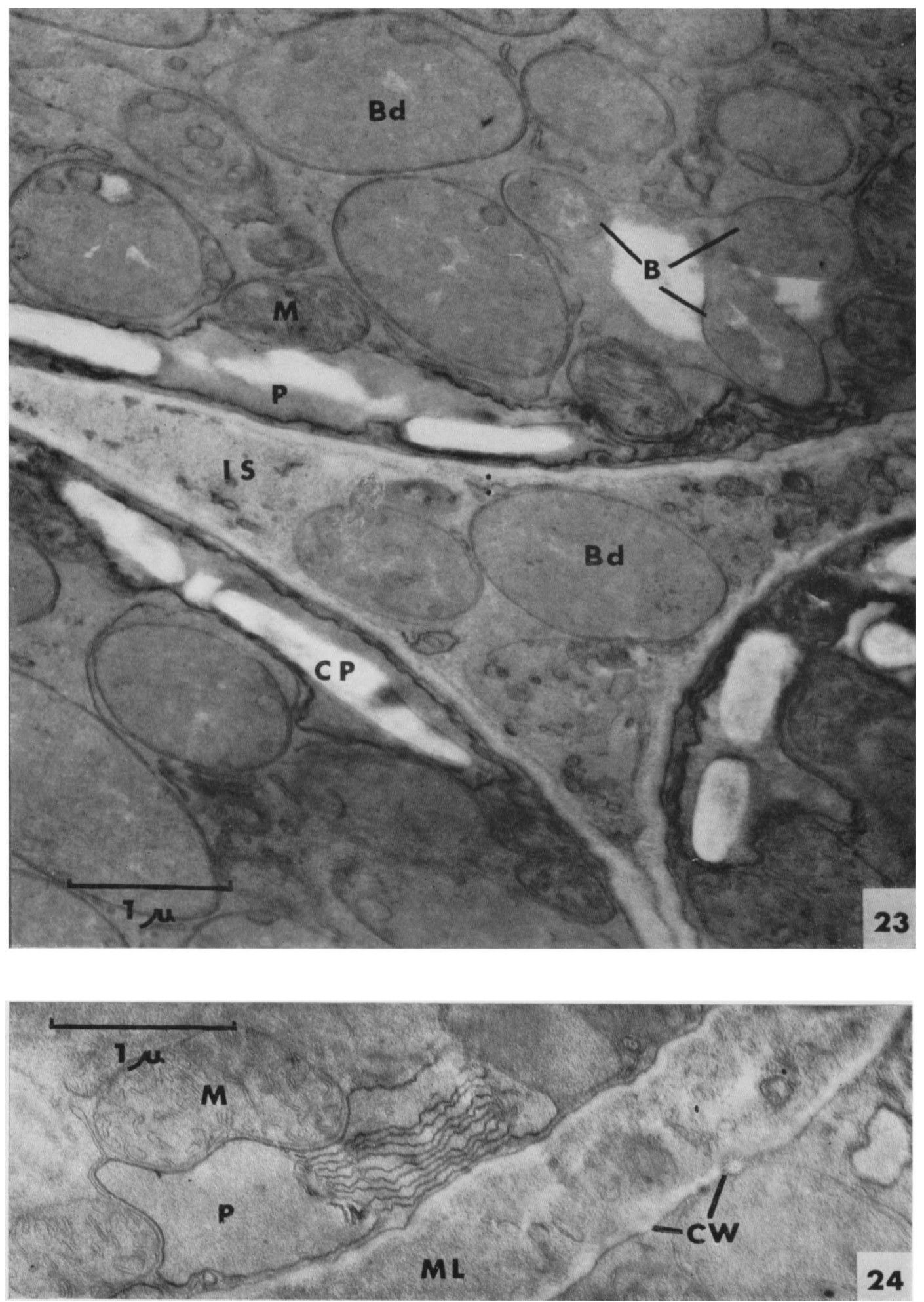
Journal of General Microbiology, Vol. 36, No. 1

Plate 14
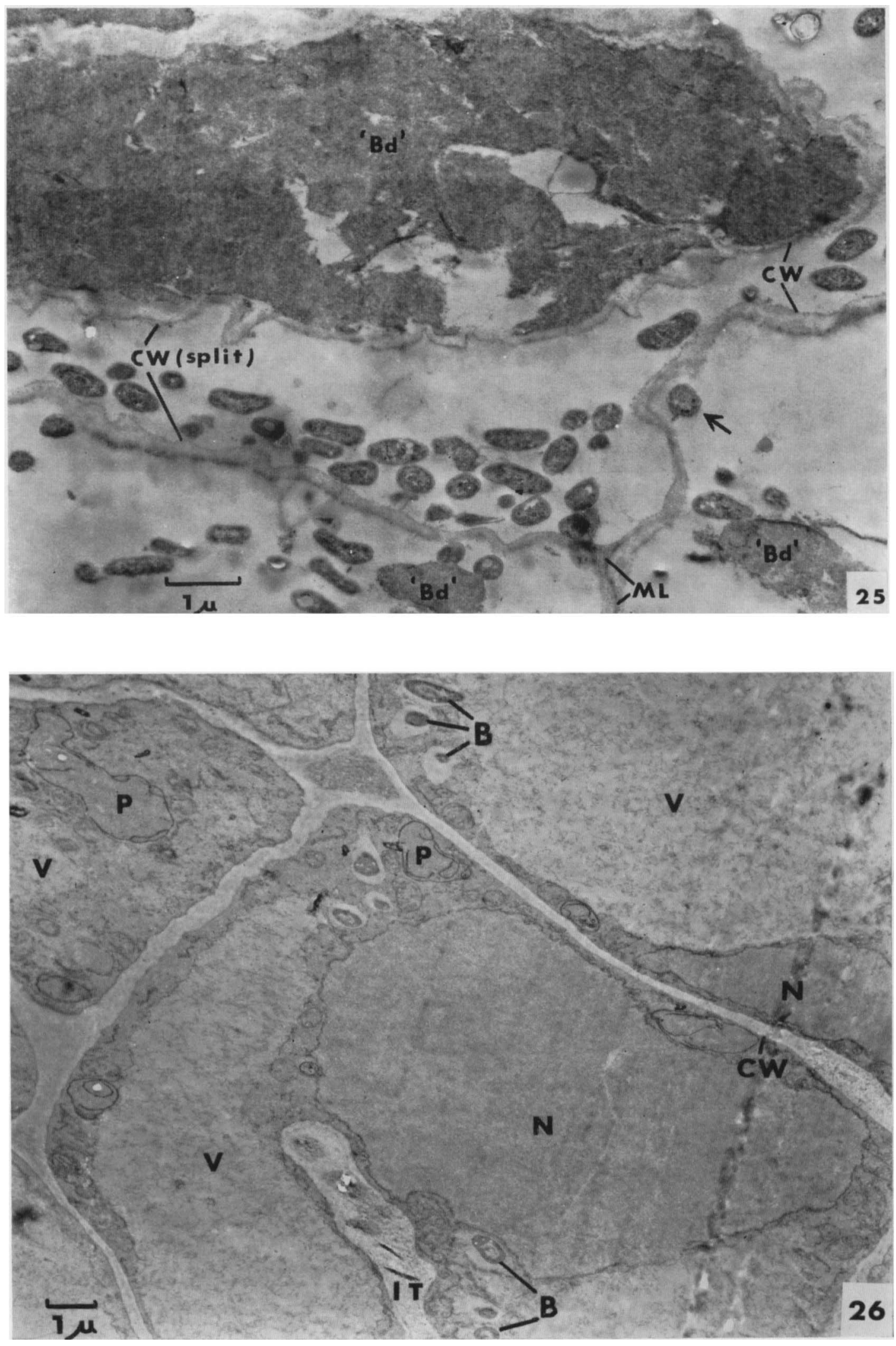

B. MOSSE 

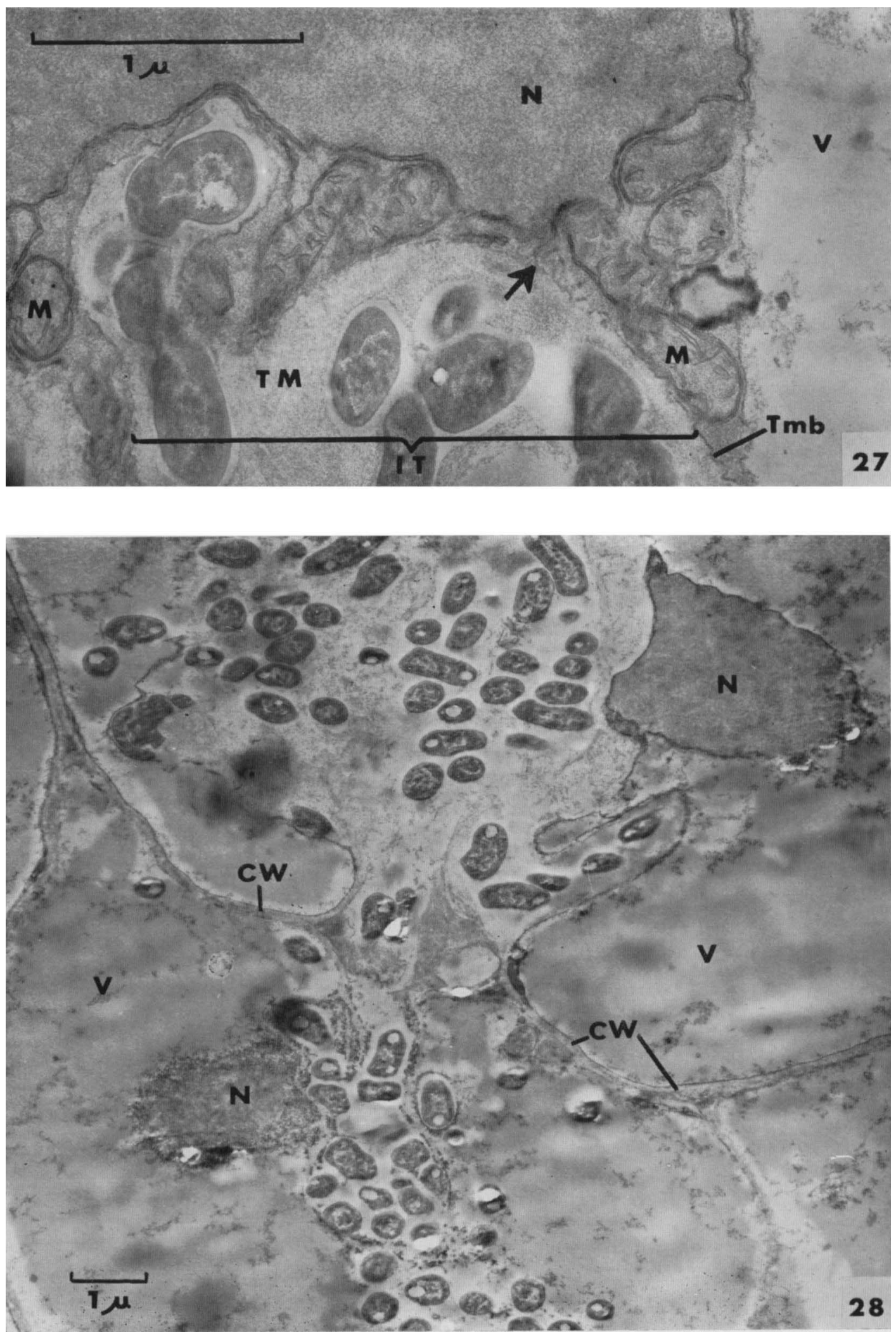

B. MOSSE 
Journal of General Microbiology, Vol. 36, No. 1

Plate 16
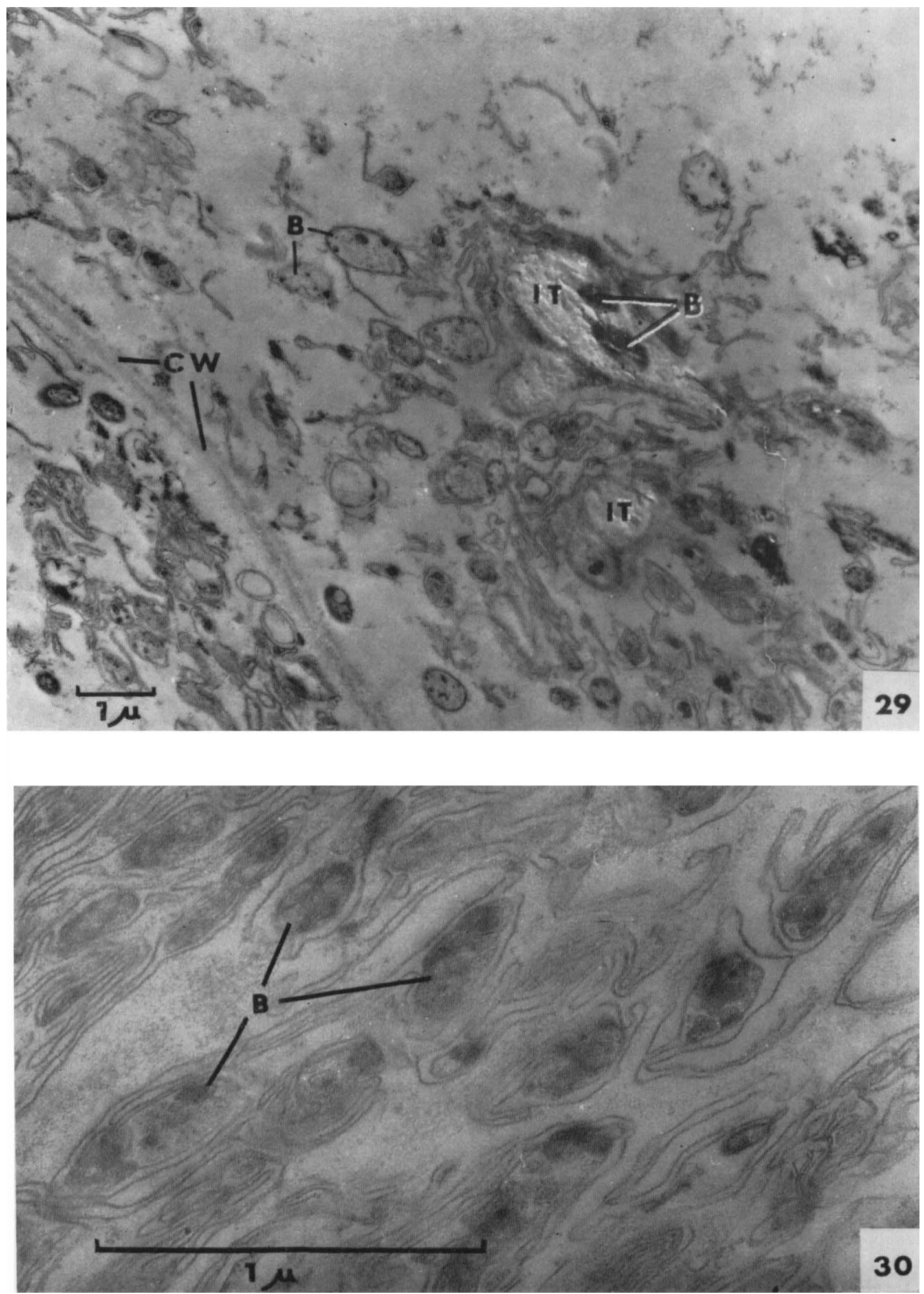

B. MOSSE 


\section{Plate 6}

Fig. 10. Lateral vesicles on an infection thread in region II. (Freezing-microtome section.)

Fig. 11. Section of a vesicle in region II. The bacteria contain transparent vacuoles (sc) interpreted as storage carbohydrates, and dense, approximately polyhedral granules resembling precursor phage particles. The arrow indicates a bacterium about to divide by budding.

\section{Plate 7}

Fig. 12. Emergence of a group of bacteria with their surrounding transparent region from a vesicle in region $I I$.

Fig. 13. Late emergence of bacteria in region III. Groups of bacteria, still surrounded by an electron-transparent zone, are enclosed by a plant membrane. The swollen bacterium (marked by arrow) is distending the enclosing membrane preparatory to emergence. Dense polyhedral particles are confined to bacteria still protected by the transparent zone or only recently emerged from it.

\section{Plate 8}

Fig. 14. Bacteria recently emerged into a meristematic cell in region $I$. At arrows the continuity of the enclosing membrane with the endoplasmic reticulum of the host cell is clearly shown. Fig. 15. Recently emerged bacteria in region $I$ of an ineffective nodule ( $T$. repens inoculated R. trifolii H.K.C.). Characteristically the enclosing membrane retains open connexion with the endoplasmic reticulum. (See also Pl. 16, fig. 30.)

Fig. 16. Rhizobia in the rhizosphere.

\section{Plate 9}

Fig. 17. Division of bacteria in the host cytoplasm (region I). The dense cytoplasm, large nucleus, Golgi body and endoplasmic reticulum are evidence of the active state of the host cell. The nuclear region of the bacteria is much contracted.

Fig. 18. Bacteria is an expanding host cell (region II) beginning their transition to the bacteroid form. Invaginations of the bacterial cytoplasmic membrane are marked by arrows. The endoplasmic reticulum of the host cell is tending to break up into vesicles, and the cytoplasm is becoming more dispersed.

\section{Plate 10}

Fig. 19. Osmium tetroxide fixation. Late stage in the transition to the bacteroid form. The small granules attached to the plant membranes (RR) are interpreted as RNA. The expanded plant membrane around the bacteria is characteristically without granules.

\section{Plate 11}

Fig. 20. Final stage in the transition to the bacteroid form. The space between the much expanded enclosing membrane and the bacterium is filled with a substance resembling vacuolar fluid. Precursors of a carbohydrate storage material laid down as rectangular platelets appear in the peripheral plastids.

\section{Plate 12}

Fig. 21. Bacteroids in region III of a nitrogen-fixing nodule of T. repens inoculated T. trifolii Cl.F. Each bacteroid has three membranes.

Fig. 22. Detail of bacteroid membranes.

\section{Plate 13}

Fig. 23. An intercellular space and parts of three adjacent cells at the boundary between regions II and III. Fully developed carbohydrate platelets characteristically occur opposite the intercellular space. The swollen bacteria in the distended space lack the enclosing membrane of host origin. Bacteria labelled $B$ are emerging into the host cytoplasm.

Fig. 24. Plastid with chloroplast-like system of parallel lamellae in nodules of $T$. repens inoculated $R$. trifolii (Cl. F.). 


\section{Plate 14,}

Fig. 25. Disintegration of host cell and bacteroids in region IV. A split cell wall containing young bacteria is situated below a cell (top of photograph) containing clumped remnants of bacteroids ('Bd'). Two disintegrating bacteroids are shown in two cells at the bottom of the photograph. A bacterium containing polyhedral particles is marked by the arrow.

Fig. 26. Early stages of infection in region $I$ of an ineffective (non-fixing) nodule of T. repens inoculated $\boldsymbol{R}$. trifolii H.K.C. Note the large vacuoles, fragmentary membranes of the host cell, electron-transparent thread matrix, and extensive transparent zones around emerged bacteria.

Fig. 27. Part of an already vacuolated cell and infection thread from region $I$ of an ineffective nodule of $T$. parviflorum inoculated $R$. trifolii Cl.F. Fibrils between the nucleus and the thread tip are indicated by an arrow.

\section{Plate 15}

Fig. 28. Rupture of the cell wall and release of bacteria into the vacuole in region II of an ineffective nodule of $T$. parviflorum inoculated $R$. trifolii H.K.C. The host cell contains only a thin lining of peripheral cytoplasm.

\section{Plate 16}

Fig. 29. Collapse of bacterial and host structure in region $I$ of an ineffective nodule of $T$. repens inoculated with $R$. trifolii H.K.C. Note the infection thread with electron-transparent matrix (middle bottom) and the appearance of lysis in the released bacteria.

Fig. 30. Extensive system of membranes surrounding emerged bacteria in an ineffective nodule of $\boldsymbol{T}$. repens inoculated $\boldsymbol{R}$. trifolii H.K.C. 